\title{
Literasi matematis dan self-efficacy siswa ditinjau dari perbedaan kebijakan sistem zonasi
}

\author{
Ahmad Muhazir ${ }^{1 *}$, Kana Hidayati ${ }^{2}$ (D) , Heri Retnawati ${ }^{2}$ \\ ${ }^{1}$ Master Program in Mathematics Education, Universitas Negeri Yogyakarta, Yogyakarta, Indonesia \\ 2 Department of Mathematics Education, Universitas Negeri Yogyakarta, Yogyakarta, Indonesia \\ * Corresponding Author. E-mail: ahmadmuhazir.2018@student.uny.ac.id
}

\begin{tabular}{ll}
\hline \multicolumn{1}{c}{ ARTICLE INFO } & \multicolumn{1}{c}{ ABSTRACT } \\
\hline Article History: & Penelitian ini bertujuan untuk (1) mendeskripsikan kemampuan literasi matematis dan self- \\
Received: 03 Dec. 2020 & efficacy siswa kelas XI SMA; (2) mendeskripsikan dampak perbedaan kebijakan sistem zonasi \\
Revised: 30 Dec. 2020 & terhadap kemampuan literasi matematis dan self-efficacy siswa kelas XI SMA; dan (3) mendes- \\
Accepted: 05 Feb. 2021 & kripsikan hubungan antara literasi matematis dan self-efficacy siswa kelas XI SMA. Penelitian \\
& survei ini melibatkan 346 siswa dari Kota Banjarmasin dan 321 siswa dari Kota Palangka Raya. \\
Keywords: & Kedua kota tersebut memiliki kebijakan zonasi yang berbeda. Pengumpulan data dilakukan me- \\
Kebijakan sistem zonasi, & lalui tes dan angket yang telah memenuhi kriteria valid dan reliabel. Teknik analisis data yang \\
Literasi matematika, & digunakan adalah statistik deskriptif dan inferensial. Hasil penelitian menunjukkan bahwa literasi \\
Mathematical literacy, & matematis siswa di Kota Banjarmasin dan Kota Palangka Raya berada pada kategori rendah, \\
Self-efficacy. & sedangkan self-efficacy siswa pada kedua kota berada pada kategori sedang. Tidak terdapat per- \\
& bedaan yang bermakna pada rata-rata literasi matematis antara siswa di Kota Banjarmasin dan \\
& Palangka Raya. Namun demikian, terdapat perbedaan yang bermakna pada rata-rata self-effi- \\
& cacy antara siswa di Kota Banjarmasin dan Palangka Raya. Kebijakan zonasi di Kota Palangka \\
& Raya menyebabkan perbedaan rata-rata literasi matematis siswa pada sekolah kategori tinggi, \\
& sedang, dan rendah. Sedangkan kebijakan zonasi di Kota Banjarmasin menyebabkan perbedaan \\
& rata-rata self-efficacy siswa pada sekolah kategori tinggi, sedang, dan rendah. Terakhir, terdapat \\
& korelasi positifyang signifikan (meskipun lemah) antara literasi matematis dan self-efficacy siswa \\
& kelas XI SMA di Kota Banjarmasin dan Kota Palangka Raya ( $r=0,194)$.
\end{tabular}

Scan me:

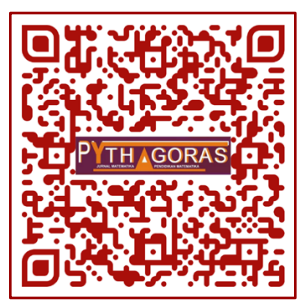

This study aimed to (1) describe the mathematical literacy abilities and self-efficacy of eleventhgrade senior high school students; (2) describe the impact of differences in zoning system policies on the mathematical literacy and self-efficacy of eleventh-grade senior high school students; and (3) describe the relationship between mathematical literacy and self-efficacy of eleventh-grade senior high school students. This survey involved 346 students from Banjarmasin City and 321 students from Palangka Raya City, Indonesia. The two cities have different zoning policies. The data was collected through tests and questionnaires that met the valid and reliable criteria. The data analysis technique used was descriptive and inferential statistics. The results showed that students' mathematical literacy in Banjarmasin and Palangka Raya City was in a low category, while self-efficacy in both cities was in the medium category. There was no significant difference in the mean of mathematical literacy of students in Banjarmasin and Palangka Raya City. However, there was a significant difference in the mean of self-efficacy of students in Banjarmasin and Palangka Raya City. The zoning policy in Palangka Raya City causes differences in the mean of mathematical literacy of students in high, moderate, and low category schools. In contrast, the zoning policy in Banjarmasin City causes differences in the mean of self-efficacy of students in high, medium, and low category schools. Lastly, there was a significant positive correlation (although weak) between mathematical literacy and self-efficacy of eleventh-grade senior high school students in Banjarmasin and Palangka Raya City ( $r=0.194)$.

This is an open access article under the CC-BY-SA license

\section{How to Cite:}

Muhazir, A., Hidayati, K., \& Retnawati, H. (2020). Literasi matematis dan self-efficacy siswa ditinjau dari perbedaan kebijakan sistem zonasi. Pythagoras: Jurnal Pendidikan Matematika, 15(2), 227-245. https://doi.org/10.21831/pg.v15i2.36255 


\section{PENDAHULUAN}

Pendidikan pada hakikatnya memiliki tujuan untuk meningkatkan kualitas hidup manusia secara berkelanjutan dan menjadi kunci konkret dalam mengembangkan kepribadian dan berpartisipasi dalam masyarakat melalui pengetahuan, nilai-nilai kemanusiaan dan keterampilan yang diperoleh untuk menjadi seorang warga negara yang terlibat aktif di masyarakat dan memiliki rasa tanggung jawab (Moretti \& Frandell, 2013; Schleicher, 2019). Digitalisasi yang masuk ke dalam berbagai macam aspek kehidupan menjadi tantangan disektor pendidikan untuk meningkatkan keterampilan dalam memberikan respons terhadap perubahan. Di era saat ini, data muncul sebagai pendukung dalam pengambilan keputusan dalam kehidupan yang sebelumnya hanya digunakan pada sektor pendidikan dan perencanaan karier, dan kemudian berkembang ke ranah kesehatan dan investasi, serta tantangan sosial utama untuk menangani berbagai hal seperti perubahan iklim, pertumbuhan populasi, penyebaran penyakit pandemik, dan ekonomi global (OECD, 2018a).

Keterampilan matematika menjadi atribut penting yang harus dimiliki semua warga negara karena matematika terlibat di setiap tingkat pemahaman seperti perubahan iklim, termasuk gambaran dan prediksi maupun konsekuensi dari perubahan tersebut (Maass et al., 2019). Matematika juga merupakan bagian dari literasi fundamental selain literasi bahasa ibu, bahasa kedua, sains, teknologi, teknik, seni budaya, komputasi atau pemrograman, keuangan, dan pendidikan kewarganegaraan sebagai salah satu kompetensi utama yang harus dimiliki siswa usia tiga sampai 18 tahun guna memenuhi visi masyarakat yang dinamis dan evolusioner dalam memberikan respons terhadap tantangan perubahan dan pembangunan nasional yang berkelanjutan (Opertti, 2017).

Organisation for Economic Cooperation and Development (OECD) menyebutkan bahwa literasi matematis merupakan kemampuan atau kapasitas yang dimiliki seorang individu dalam merumuskan, menggunakan, dan menafsirkan matematika ke berbagai konteks, termasuk di dalamnya kemampuan bernalar secara matematis dan kemampuan menggunakan konsep, prosedur, fakta dan fungsi matematika untuk menggambarkan, menjelaskan dan memprediksi suatu fenomena. Literasi matematis membantu individu untuk memahami peran atau kegunaan matematika dalam kehidupan sehari-hari dan menggunakannya untuk membuat penilaian dan mengambil keputusan-keputusan yang logis sebagai warga negara yang bertanggung jawab, peduli, dan memiliki pola pikir yang konstruktif (OECD, 2019c, p. 75). Definisi ini kemudian diperluas pada dokumen kerangka kerja PISA 2021 dengan menampilkan aspek hubungan penalaran dan proses pemodelan matematika dengan konten dan konteks matematika sebagai keterampilan abad 21 (OECD, 2018a).

Definisi dari literasi matematis memberikan gambaran bahwa keterampilan ini bukan hanya seperangkat keterampilan dalam menentukan deret atau angka yang terputus maupun komputasi sederhana dari suatu bilangan, melainkan literasi ini melibatkan dunia nyata dalam konteks yang bersifat menyeluruh yang dapat membantu seseorang dalam memahami masalah, mempertimbangkan untuk menemukan kemungkinan yang lebih baik, meminimalkan kendala, dan merepresentasikan model untuk memahami berbagai pola kemungkinan yang akan terjadi (Hoyles et al., 2010). Seseorang yang memiliki kemampuan literasi matematis dapat meningkatkan pemahamannya tentang fenomena dunia nyata yang akan mendukung pengambilan keputusan yang baik di semua bidang kehidupan, terlebih bagi masyarakat modern yang memiliki ketergantungan pada kemajuan teknologi (OECD \& UNESCO Institute for Statistics, 2003; Stacey \& Turner, 2015).

Peranan penting literasi matematis menjadi perhatian OECD untuk melaksanakan survei tiga tahunan yang dinamai Programme for International Student Assessment (PISA) dengan tujuan memberikan gambaran seberapa siap siswa remaja dalam menghadapi tantangan masa depan, tidak hanya siswa di satu negara tetapi di berbagai negara di dunia (OECD, 2000). Hasil PISA 2018 menunjukkan bahwa rata-rata di seluruh negara OECD, satu dari empat siswa usia 15 tahun tidak mencapai level kecakapan minimum dalam matematika, sedangkan $76 \%$ siswa mampu mencapai Level 2 atau lebih tinggi dalam matematika (OECD, 2019b). Hasil ini memberikan gambaran bahwa setidaknya siswa dapat menafsirkan dan mengenali bagaimana situasi (sederhana) dapat direpresentasikan secara matematis tanpa instruksi langsung. Lebih dari 50\% siswa di 24 negara mendapat nilai di bawah level 2 (OECD, 2019d). Siswa dengan level literasi matematis di bawah level 2 mampu menyelesaikan permasalahan yang melibatkan konteks yang sering terjadi di sekitar mereka yang mana semua informasi yang diperlukan tersaji dengan jelas (OECD, 2019c). Hal yang paling tidak diinginkan dari rendahnya kemampuan literasi matematis adalah tidak hanya terkait akses pekerjaan yang terbatas, tetapi juga terkait dengan kesehatan yang kurang baik dan sedikitnya partisipasi sosial dan politik dalam bernegara (OECD, 2016a). 
Indonesia termasuk ke dalam 24 negara yang literasi matematis siswanya didominasi oleh level 2 ke bawah (28\% level 2 atau di atasnya dan $1 \%$ level 5 atau di atasnya) (OECD, 2019a). Menurut hasil PISA 2015, meski masih berada di angka yang jauh di bawah rata-rata negara OECD, Indonesia menempatkan diri pada empat besar dalam hal kenaikan pencapaian siswa dibanding hasil survei sebelumnya, sehingga diyakini jika peningkatan tersebut terus berlanjut secara konsisten, Indonesia dapat menyamai negara-negara lain dalam 15 tahun, yaitu pada tahun 2030 (OECD, 2016b). Akan tetapi, pada hasil PISA 2018 menunjukkan penurunan sehingga dapat dikatakan cenderung fluktuatif sejak tahun 2000 (lihat Gambar 1). Dilihat berdasarkan urutan, Indonesia berada pada peringkat 72 dari 78 negara yang berpartisipasi dengan skor rata-rata 379 untuk literasi matematis (selisih 7 angka dari PISA 2015) dan rata-rata negara OECD sebesar 489 (OECD, 2019d).

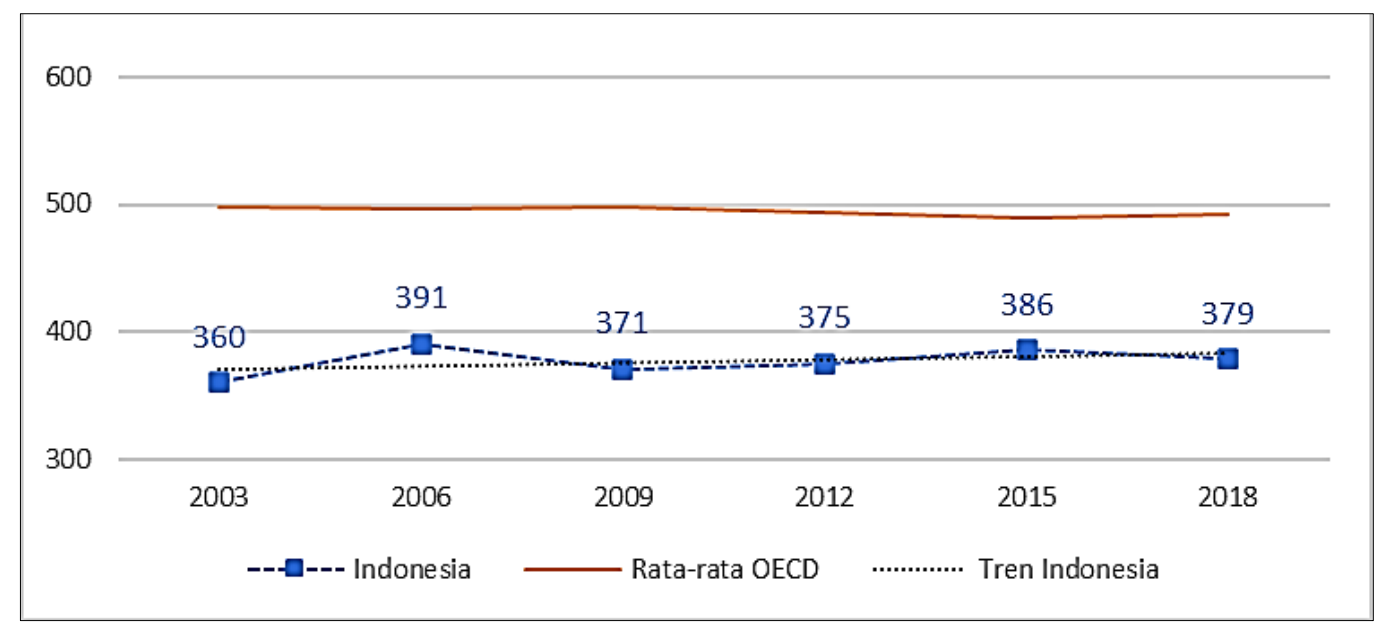

Gambar 1. Tren pencapaian literasi matematis siswa Indonesia (Sumber: OECD, 2019a, p. 3)

Hasil studi PISA perlu ditindaklanjuti oleh pemerintah Indonesia untuk terus meningkatkan mutu pendidikan. Penilaian berskala internasional seperti yang dilakukan PISA tersebut dapat memberikan acuan kepada para pembuat kebijakan dan praktisi alat yang berguna untuk meningkatkan kualitas, kesetaraan, dan efisiensi dalam bidang pendidikan (OECD, 2013; Schleicher, 2007). Penilaian terhadap literasi matematis dalam skala daerah juga perlu untuk dilakukan mengingat luasnya daerah dan ragam budaya Indonesia serta sistem otonomi daerah yang dianut pemerintah Indonesia.

Faktor yang mempengaruhi capaian literasi matematis di Indonesia juga perlu diidentifikasi. Meningkatnya faktor yang memiliki dampak positif terhadap prestasi matematika diharapkan mampu meningkatkan literasi matematis siswa Indonesia. Faktor yang berdampak terhadap pencapaian seseorang dalam matematika secara garis besar terdiri dari dua faktor, yaitu faktor internal dan eksternal (OECD, 2018b; Schleicher, 2019). Mourshed et al. (Asrijanty, 2019; Cheema \& Skultety, 2016) menunjukkan bahwa faktor yang paling berpengaruh dalam pencapaian matematika siswa adalah mindset, yaitu sikap dan kepercayaan siswa secara umum terhadap matematika. Hasil studi juga mengungkapkan bahwa pada skor literasi matematis yang tinggi, kepercayaan terhadap kemampuan atau self-efficacy-nya juga tinggi (Tutkun et al., 2014).

Self-efficacy diartikan sebagai penilaian individu terhadap kemampuannya dalam menangani masalah-masalah tertentu (Bandura, 1995, 1997). Self-efficacy berhubungan dengan keyakinan seseorang bahwa dia dapat melakukan sesuatu yang memadai untuk menghadapi situasi tertentu (Gibson et al., 2011). Self-efficacy tidak hanya meyakini bahwa diri memiliki kemampuan, tetapi juga mendorong untuk berhasil dalam menghadapi permasalahan (McCoach et al., 2013). Self-efficacy seseorang akan memberikan informasi dalam menentukan seberapa besar usaha yang diperlukan dan seberapa besar dia dapat bertahan untuk mengatasi suatu masalah, bahkan untuk situasi yang tidak menguntungkan bagi dirinya. Semakin tinggi self-efficacy seseorang, semakin besar upaya, ketekunan, dan ketahanan dalam menghadapi permasalahan yang sulit sebagai tantangan yang harus dihadapi dan memilih untuk tidak menghindarinya (Pajares, 2005). Self-efficacy juga menggambarkan harapan seseorang untuk sukses, di mana pencapaian sebelumnya juga menjadi acuan untuk memberikan informasi sejauh mana dia mampu atau sukses dalam memberikan kinerjanya (Simon et al., 2015).

Permasalahan atau soal-soal yang diberikan PISA merupakan permasalahan dalam bentuk situasi kompleks yang memerlukan keterampilan berpikir dan penalaran yang baik (Wijaya et al., 2014). Permasalahan seperti ini 
akan menjadi tantangan bagi siswa dengan self-efficacy tinggi. Temuan-temuan lain juga mengindikasikan bahwa self-efficacy merupakan alat prediksi terbaik terhadap pencapaian siswa dalam konteks pendidikan (Carmichael et al., 2010; Tossavainen et al., 2019). Sebagai faktor yang memiliki dampak positif terhadap pencapaian siswa, selfefficacy penting untuk diperhatikan. Gambaran mengenai tingkatan self-efficacy di suatu lingkungan pendidikan dapat memberikan acuan untuk mengambil langkah yang tepat guna meningkatkan pandangan dan persepsi siswa terhadap suatu permasalahan.

Faktor lain yang juga penting untuk diperhatikan sehubungan dengan penyebab rendahnya skor PISA Indonesia adalah mutu pendidikan yang belum merata secara menyeluruh di seluruh wilayah Indonesia. Berdasarkan kalkulasi yang dilakukan oleh Aditomo dan Felicia (2018), data PISA 2015 memberikan gambaran bahwa sekolah yang memiliki capaian rendah jika dibandingkan berdasarkan lamanya tahun pelajaran, hampir setara 2 tahun tertinggal dengan sekolah yang memiliki capaian tinggi pada literasi matematis. Oleh karena itu, setiap daerah di Indonesia wajib memperbaiki dan meningkatkan mutu pendidikan dan sekolahnya agar tidak tertinggal dari daerah lain. Pemerintah telah melakukan upaya guna memperbaiki rendahnya skor literasi siswa. Upaya tersebut ditandai dengan diterapkannya gerakan literasi sekolah yang diintegrasikan ke dalam Kurikulum 2013 (Wiedarti \& Laksono, 2016). Selanjutnya, ada kebijakan sistem zonasi yang telah diterapkan sejak tahun 2017 (Kemendikbud, 2019). Menurut McCulloch (1991), kebijakan zonasi penting untuk diterapkan dalam rangka meminimalkan kesenjangan antara sekolah maju dan sekolah yang tergolong tertinggal.

Kebijakan zonasi telah diterapkan di beberapa daerah di Indonesia, termasuk di Kota Banjarmasin, Kalimantan Selatan dan Kota Palangka Raya, Kalimantan Tengah. Namun demikian, kedua kota memiliki aturan yang berbeda dalam penerapan kebijakan sistem zonasi ditinjau dari tiga jalur yang ada, yaitu jalur zonasi, prestasi, dan afirmasi (perpindahan orang tua). Bedanya, di Kota Banjarmasin, seleksi penerimaan peserta didik baru tahun pelajaran 2019/2020 pada jalur zonasi berdasarkan jarak tempat tinggal dengan sekolah (Dinas Pendidikan dan Kebudayaan Pemerintah Provinsi Kalimantan Selatan, 2019), sedangkan di Kota Palangka Raya, seleksi penerimaan peserta didik baru tahun pelajaran 2019/2020 pada jalur zonasi berdasarkan hasil penjumlahan antara skor jarak tempat tinggal (skor 100 untuk jarak kurang dari 5 km, skor 85 untuk jarak 5 km sampai dengan $10 \mathrm{~km}$, skor 70 untuk jarak $10 \mathrm{~km}$ sampai dengan $15 \mathrm{~km}$, dan skor 55 untuk jarak lebih dari $15 \mathrm{~km}$ ) dengan nilai Ujian Nasional (UN) (Dinas Pendidikan Pemerintah Provinsi Kalimantan Tengah, 2019). Adapun untuk seleksi penerimaan peserta didik baru melalui jalur prestasi, di Kota Banjarmasin ditentukan berdasarkan jumlahan antara nilai prestasi akademik/non-akademik dan nilai UN, sedangkan di Kota Palangka Raya hanya ditentukan berdasarkan nilai prestasi akademik/non-akademik. Terakhir, untuk jalur afirmasi (perpindahan orang tua), baik di Kota Banjarmasin maupun Kota Palangka Raya, seleksi penerimaan peserta didik baru ditentukan berdasarkan nilai UN.

Mengacu pada perbedaan kebijakan zonasi yang diterapkan di Kota Banjarmasin dan Kota Palangka Raya serta dengan memperhatikan nilai Ujian Nasional siswa pada jenjang SMP sebagai kemampuan awal (prior achievement), perbedaan kebijakan zonasi dapat memberikan dampak terhadap sebaran literasi matematis dan selfefficacy siswa. Prior achievement telah terbukti memiliki dampak terhadap pencapaian siswa di masa berikutnya (Hemmings et al., 2011; Kriegbaum et al., 2015).

Penelitian terdahulu terkait literasi matematis telah dilakukan beberapa ahli di daerah-daerah di Indonesia. Hamidy dan Jailani (2019) telah meneliti kemampuan literasi matematis siswa sekolah menengah di Provinsi Kalimantan Timur. Penelitian-penelitian terdahulu lebih berfokus pada satu daerah seperti yang dilakukan oleh Rifai dan Wutsqa (2017) dan Sari dan Wijaya (2017) yang melakukan penelitian terkait literasi matematis di Kabupaten Bantul dan D. I. Yogyakarta. Selain itu, Mahdiansyah dan Rahmawati (2014) melakukan penelitian di beberapa kota di Indonesia namun lebih berfokus pada variabel literasi matematis saja. Adapun penelitian yang telah dilakukan oleh Samsuddin (2019) telah memberikan pandangan lain dengan memperhatikan hubungan self-efficacy dan literasi matematis. Berdasarkan paparan tersebut, penelitian ini lebih difokuskan untuk mendeskripsikan dan menganalisis hubungan antara literasi matematis dan self-efficacy siswa SMA di dua kota yang menerapkan sistem zonasi yang berbeda.

\section{METODE}

Penelitian ini merupakan penelitian survei yang dilaksanakan di Kota Banjarmasin dan Kota Palangka Raya. Penelitian berlangsung dari tanggal 24 Juli 2020 sampai dengan 21 September 2020. Populasi penelitian ini adalah seluruh siswa kelas XI SMA di Kota Banjarmasin untuk tahun ajaran 2020/2021 yang berjumlah 3390 siswa dari 13 SMA Negeri di Kota Banjarmasin dan seluruh siswa SMA kelas XI di Kota Palangka Raya tahun ajaran 2020/2021 
yang berjumlah 1923 siswa dari 8 SMA Negeri di Kota Palangka Raya (Kemendikbud, n.d.). Sampel penelitian diperlukan mengingat besarnya ukuran populasi. Pengambilan sampel dilakukan dengan menggunakan teknik stratified random sampling. Besaran dari ukuran sampel dihitung berdasarkan rumus Krejcie dan Morgan (1970). Berdasarkan rumus tersebut, diperoleh ukuran sampel minimal untuk Kota Banjarmasin berjumlah 346 siswa dan untuk Kota Palangka Raya berjumlah 321 siswa. Karakteristik subjek penelitian dalam penelitian ini adalah siswa kelas XI yang memiliki usia pada rentang $15-16$ tahun. Rentang usia tersebut tidak berbeda jauh dengan siswa yang mengikuti survei literasi matematis PISA (15 tahun).

Siswa dari enam sekolah di Kota Banjarmasin dan enam sekolah di Kota Palangka Raya dipilih secara acak untuk menjadi bagian dari sampel penelitian. Sekolah kemudian dikategorikan menjadi tiga, yaitu A, B, dan C yang dikategorikan berdasarkan rata-rata $(\bar{x})$ hasil UN SMA tahun 2019 untuk Kota Banjarmasin dan Kota Palangka Raya dengan mengacu pada kriteria yang dirumuskan Ebel dan Frisbie (1991). Kategori sekolah untuk Kota Banjarmasin adalah A $(59,56 \leq \bar{x})$, B $(51,57 \leq \bar{x}<59,56)$, dan C $(\bar{x}<51,57)$. Adapun kategori sekolah untuk Kota Palangka Raya adalah $\mathrm{A}(52,36 \leq \bar{x}), \mathrm{B}(45,73 \leq \bar{x}<52,36)$, dan C $(\bar{x}<45,73)$. Dua sekolah dari masing-masing kategori dipilih secara acak untuk Kota Banjarmasin dan Kota Palangka Raya. Selanjutnya, menentukan dua kelas secara acak yang siswanya dijadikan sebagai sampel penelitian. Ukuran sampel masing-masing kategori sekolah di Kota Banjarmasin dan Kota Palangka Raya dapat dilihat dalam Tabel 1.

Tabel 1. Ukuran sampel untuk masing-masing kategori sekolah di Kota Banjarmasin dan Palangka Raya

\begin{tabular}{llclc}
\hline Kategori & Kota Banjarmasin & $n$ & Kota Palangka Raya & $n$ \\
\hline A & SMA Negeri 1 Banjarmasin & 60 & SMA Negeri 1 Palangka Raya & 67 \\
& SMA Negeri 2 Banjarmasin & 60 & SMA Negeri 2 Palangka Raya & 67 \\
B & SMA Negeri 3 Banjarmasin & 55 & SMA Negeri 3 Palangka Raya & 64 \\
& SMA Negeri 6 Banjarmasin & 62 & SMA Negeri 4 Palangka Raya & 40 \\
C & SMA Negeri 9 Banjarmasin & 59 & SMA Negeri 6 Palangka Raya & 41 \\
& SMA Negeri 10 Banjarmasin & 50 & SMA Negeri 10 Palangka Raya & 42 \\
Sub total & & 346 & & 321 \\
Total & & 667 & & \\
\hline
\end{tabular}

Pengumpulan data pada penelitian ini dilakukan secara online dengan media Google Forms yang terdiri atas instrumen tes tertulis literasi matematis dan angket self-efficacy. Adapun waktu pengerjaan adalah 1 jam 25 menit untuk tes literasi matematis dan 15 menit untuk mengisi angket self-efficacy. Instrumen tes tertulis terdiri atas 12 butir soal yang disusun berdasarkan framework PISA 2018. Setiap butir soal mewakili setiap domain yang ada dalam framework PISA, yaitu domain proses, konten, dan konteks. Angket self-efficacy terdiri atas 24 butir pernyataan dengan skala Likert (lima pilihan respons) yang disusun berdasarkan dimensi self-efficacy yang dikemukakan oleh Bandura $(1995,1997)$, yaitu dimensi level/magnitude, strength, dan generality. Rincian mengenai distribusi setiap domain soal literasi matematis dan indikator untuk masing-masing dimensi self-efficacy dapat dilihat dalam Tabel 2 dan Tabel 3. Tes tertulis dan angket disusun berdasarkan tujuan penelitian, yaitu untuk memperolah gambaran mengenai literasi matematis dan self-efficacy siswa dan telah divalidasi oleh tiga ahli yang berprofesi sebagai dosen pendidikan matematika. Hasil uji coba yang dilakukan menghasilkan estimasi koefisien reliabilitas sebesar 0,910 untuk instrumen literasi matematis dan sebesar 0,904 untuk angket self-efficacy. Dengan demikian, kedua instrumen yang digunakan dalam penelitian ini telah memenuhi standar minimum reliabilitas instrumen yang baik (Ebel \& Frisbie, 1991).

Tabel 2. Distribusi domain proses, konten, dan konteks pada soal model PISA

\begin{tabular}{ccccc}
\hline & \multicolumn{4}{c}{ Domain konten } \\
\cline { 2 - 5 } & Quantity & Shape and space & Change and relationship & Uncertainty and data \\
\hline Domain proses: & & & & \\
Employ & Unit $5 \mathrm{~A}^{\mathrm{a}}$ & Unit $1 \mathrm{~A}^{\mathrm{d}}$ & Unit $4 \mathrm{~B}^{\mathrm{b}}$ & Unit $5 \mathrm{~B}^{\mathrm{a}}$ \\
Formulate & Unit $4 \mathrm{~A}^{\mathrm{b}}$ & Unit $3 \mathrm{~B}^{\mathrm{c}}$ & Unit $1 \mathrm{~B}^{\mathrm{d}}$ & Unit 3A \\
Interpret & Unit $2 \mathrm{~A}^{\mathrm{c}}$ & Unit $4 \mathrm{C}^{\mathrm{b}}$ & Unit $4 \mathrm{D}^{\mathrm{a}}$ & Unit $2 \mathrm{~B}^{\mathrm{c}}$ \\
\hline
\end{tabular}

Keterangan:

${ }^{a}$ konteks societal, ${ }^{b}$ konteks scientific, ${ }^{c}$ konteks personal, ${ }^{d}$ konteks occupational 
Tabel 3. Indikator masing-masing dimensi self-efficacy

\begin{tabular}{lll}
\hline Dimensi & Indikator & Contoh butir pernyataan \\
\hline Level & Keyakinan terhadap kemampuan untuk dapat & Saya ragu dapat menyelesaikan soal mate- \\
& menyelesaikan permasalahan matematika & matika yang berbeda dengan apa yang \\
& dengan berbagai tingkat kesulitan yang berbeda & dicontohkan oleh guru \\
Strength & Gigih, tekun, dan ulet dalam menyelesaikan & Saya tidak memiliki keinginan untuk ber- \\
& permasalahan matematika yang diberikan dan & tanya atau mencari referensi lain, \\
& meyakini bahwa usaha yang telah dilakukan & walaupun ada materi matematika yang \\
& memberikan dampak yang positif & belum saya paham \\
Generality & Keyakinan untuk mampu untuk menyelesaikan & Saya yakin mampu menyelesaikan soal ujian \\
& masalah meskipun dalam keadaan yang tidak & matematika dengan baik, meskipun dilak- \\
& menguntungkan & sanakan secara mendadak \\
\hline
\end{tabular}

Teknik analisis data yang digunakan adalah statistik deskriptif dan statistik inferensial. Statistik deskriptif dilakukan untuk menggambarkan literasi matematis dan self-efficacy siswa secara umum. Kategori dari skor literasi matematis mengacu pada kategori pencapaian kompetensi Badan Standar Nasional Pendidikan (2018). Sedangkan hasil skor self-efficacy siswa dikategorikan menurut skala interval Ebel dan Frisbie (1991). Kategori skor literasi matematis dan self-efficacy siswa yang dapat dilihat dalam Tabel 4. Adapun statistik inferensial digunakan untuk menganalisis dampak perbedaan zonasi terhadap literasi matematis dan self-efficacy siswa melalui uji-t dan ANOVA. Dalam menganalisis hubungan antara self-efficacy dan literasi matematis, digunakan uji korelasi Pearson.

Tabel 4. Kategori skor literasi matematis dan self-efficacy

\begin{tabular}{lcc}
\hline \multirow{2}{*}{ Kategori capaian } & \multicolumn{2}{c}{ Interval skor } \\
\cline { 2 - 3 } & Literasi matematis $\left(X_{1}\right)$ & Self-efficacy $\left(X_{2}\right)$ \\
\hline Sangat tinggi & $85<X_{1} \leq 100$ & $96<X_{2} \leq 120$ \\
Tinggi & $70<X_{1} \leq 85$ & $80<X_{2} \leq 96$ \\
Sedang & $55<X_{1} \leq 70$ & $64<X_{2} \leq 80$ \\
Rendah & $X_{1} \leq 55$ & $48<X_{2} \leq 64$ \\
Sangat rendah & & $24<X_{2} \leq 48$ \\
\hline
\end{tabular}

HASIL PENELITIAN

\section{Literasi Matematis Siswa Kelas XI SMA di Kota Banjarmasin dan Kota Palangka Raya}

Secara umum, skor literasi matematis siswa kelas XI SMA di Kota Banjarmasin dan Kota Palangka Raya berada pada kategori rendah dengan rata-rata perolehan skor berturut-turut adalah 30,65 dan 28,15. Rata-rata skor untuk kedua kota adalah 29,45, di mana ini masuk ke dalam kategori rendah. Data mengenai skor literasi matematis siswa kelas XI SMA di Kota Banjarmasin dan Palangka Raya secara lebih lengkap dapat dilihat dalam Tabel 5.

Tabel 5. Perbandingan skor literasi matematis di Kota Banjarmasin dan Kota Palangka Raya

\begin{tabular}{lccr}
\hline Deskripsi & Kota Banjarmasin & Kota Palangka Raya & Keseluruhan \\
\hline Rata-rata & 30,65 & 28,15 & 29,45 \\
Standar deviasi & 26,72 & 27,22 & 26,97 \\
Varians & 713,97 & 741,10 & 727,50 \\
Skor tertinggi & 97,83 & 95,65 & 97,83 \\
Skor terendah & 0 & 0 & 0 \\
\hline
\end{tabular}

Berdasarkan kategori skor, siswa SMA kelas XI di Kota Banjarmasin dan Kota Palangka Raya yang mencapai skor sangat tinggi kurang dari $2 \%$ dan sekitar $80 \%$ di antaranya berada pada kategori rendah. Gambar 2 menunjukkan bahwa persentase siswa di Kota Banjarmasin dan Palangka Raya secara keseluruhan cenderung turun berdasarkan kategori skor literasi matematis dari rendah ke sangat tinggi. Hasil ini menunjukkan bahwa semakin tinggi skor literasi matematis, semakin rendah persentase siswa yang mencapainya. 


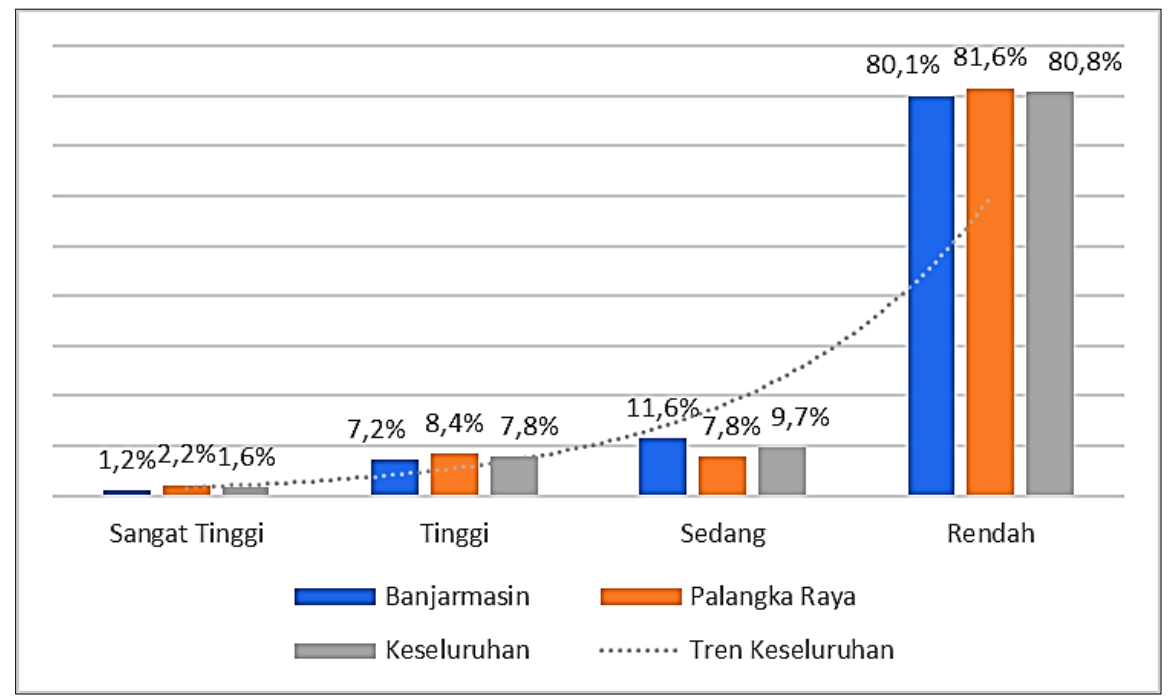

Gambar 2. Kategori skor literasi matematis Kota Banjarmasin dan Kota Palangka Raya

Perbandingan rata-rata skor literasi matematis siswa pada sekolah dengan kategori A, B, dan C untuk Kota Banjarmasin dan Kota Palangka Raya secara umum dijelaskan pada Gambar 3. Berdasarkan kategori sekolah, ratarata skor literasi matematis siswa pada sekolah dengan kategori A, B, dan C untuk secara keseluruhan masingmasing sebesar 35,23; 31,38; dan 19,59. Untuk masing-masing kota, rata-rata tertinggi didominasi oleh sekolah dengan kategori A, yaitu 31,23 (rendah) untuk Kota Banjarmasin dan 38,81 (rendah) untuk Kota Palangka Raya. Siswa dengan skor literasi matematis tertinggi untuk masing-masing kota juga berasal dari sekolah kategori A, yaitu 97,83 untuk Kota Banjarmasin dan 95,65 untuk Kota Palangka Raya. Lebih lanjut, kemampuan literasi matematis siswa di Kota Palangka Raya cenderung didominasi oleh sekolah kategori A dan B. Hal ini menunjukkan bahwa siswa yang berada pada sekolah kategori A dan B di Kota Palangka Raya memiliki peluang lebih besar untuk memperoleh skor sangat tinggi dibanding siswa yang berada pada sekolah kategori $\mathrm{C}$. Hal yang berbeda terjadi di Kota Banjarmasin, di mana skor literasi matematis berdasarkan kategori sekolah cenderung merata untuk kategori A, B, dan C.

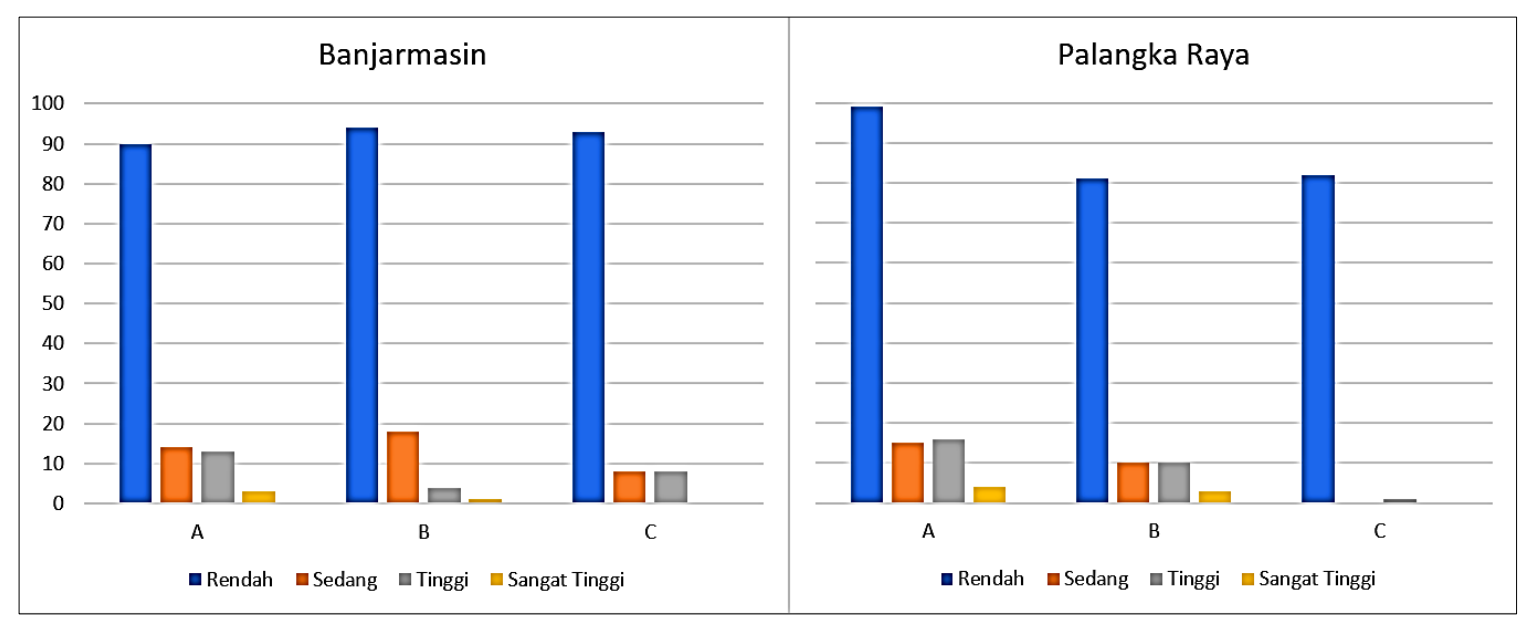

Gambar 3. Kemampuan literasi matematis siswa berdasarkan kategori sekolah di Kota Banjarmasin dan Kota Palangka Raya

Literasi Matematis Siswa Kelas XI SMA Kota Banjarmasin dan Kota Palangka Raya Berdasarkan Domain Proses, Konten, dan Konteks

Kemampuan literasi matematis domain proses terdiri dari tiga komponen, yaitu employ, formulate, dan interpret. Secara keseluruhan, kemampuan employ, formulate, dan interpret siswa berada pada kategori rendah dengan rata-rata skor masing-masing 34,07; 27,35; dan 26,57. Gambaran mengenai kemampuan proses employ, formulate, dan interpret yang lebih rinci dapat dilihat pada Gambar 4. 


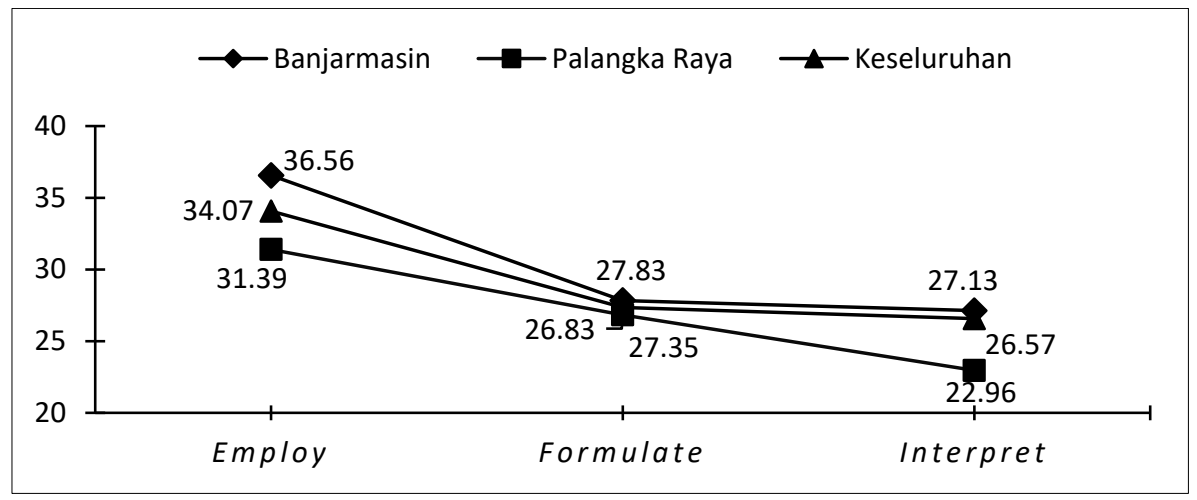

Gambar 4. Kemampuan domain proses siswa di Kota Banjarmasin dan Kota Palangka Raya

Konten literasi matematis berdasarkan framework PISA terbagi menjadi empat komponen, yaitu quantity, change and relationship, shape and space, dan uncertainty and data. Secara keseluruhan, kemampuan literasi matematis berdasarkan domain konten siswa di Kota Banjarmasin dan Kota Palangka Raya berada pada kategori rendah dengan masing-masing rata-rata skor sebesar 32,2; 27,6; 29,8; dan 27,9. Secara rinci, kemampuan domain konten siswa Kota Banjarmasin dan Kota Palangka Raya dapat dilihat pada Gambar 5.

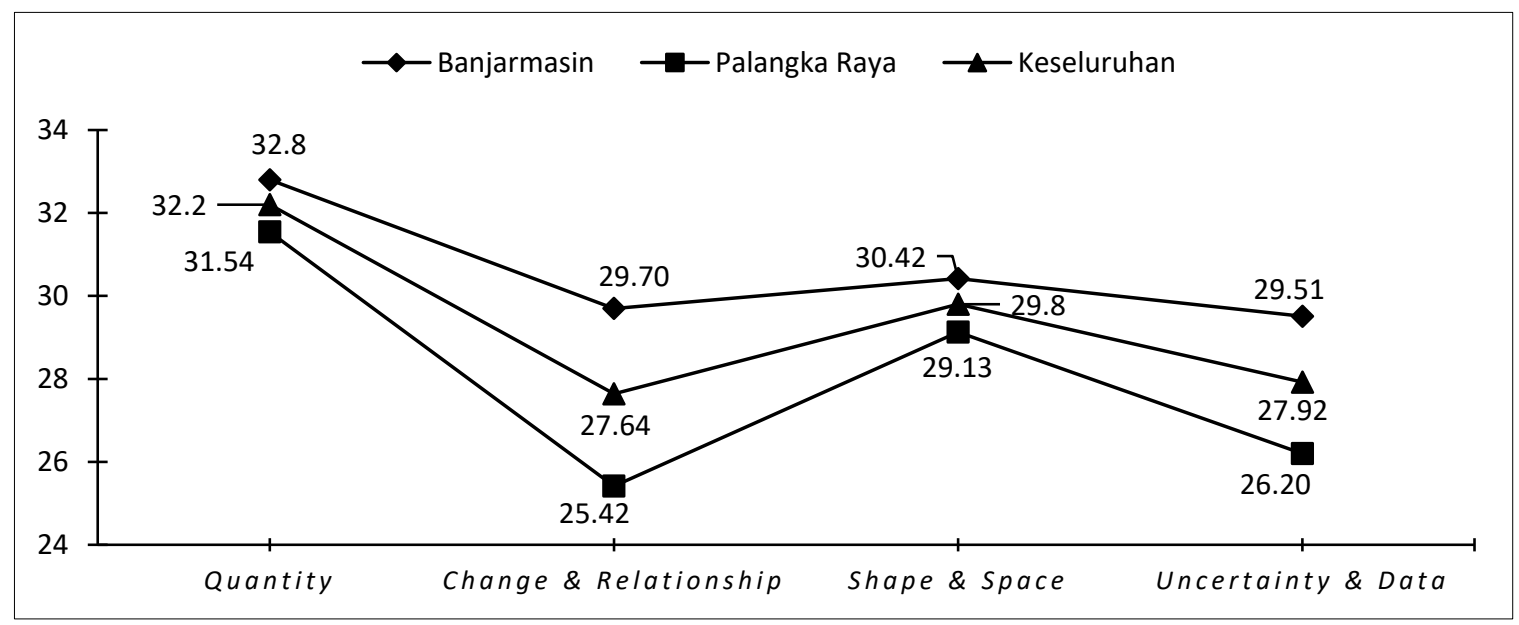

Gambar 5. Kemampuan domain konten siswa di Kota Banjarmasin dan Kota Palangka Raya

Konteks literasi matematis berdasarkan framework PISA terbagi menjadi empat komponen, yaitu personal, occupational, scientific, dan societal. Secara keseluruhan, kemampuan literasi matematis siswa di Kota Banjarmasin dan Kota Palangka Raya terendah pada komponen scientific dan societal dengan rata-rata skor 20,4. Secara rinci, kemampuan literasi matematis siswa di Kota Banjarmasin dan Kota Palangka Raya jika dilihat berdasarkan domain konteks dapat dilihat pada Gambar 6.

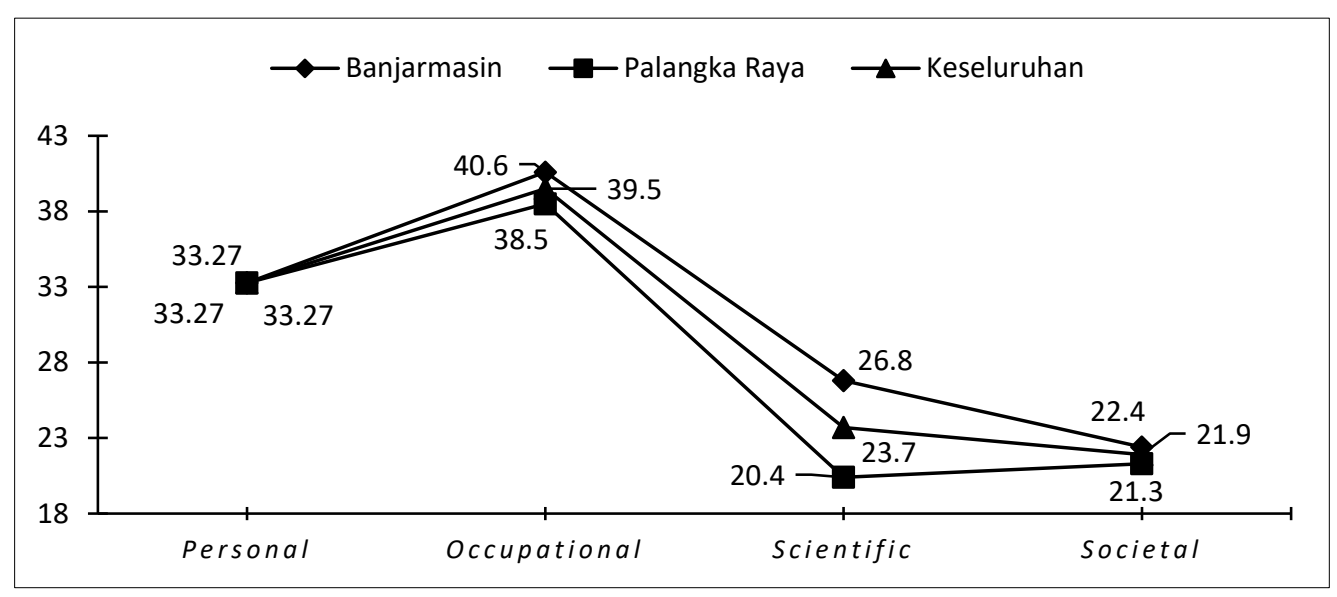

Gambar 6. Kemampuan domain konten siswa di Kota Banjarmasin dan Kota Palangka Raya 


\section{Self-Efficacy Siswa Kelas XI SMA di Kota Banjarmasin dan Kota Palangka Raya}

Self-efficacy siswa kelas XI SMA di Kota Banjarmasin dan Kota Palangka Raya berada pada kategori sedang, dengan skor rata-rata masing-masing adalah 76,41 dan 79,08 serta rata-rata keseluruhan adalah 77,7 (sedang). Berdasarkan masing-masing dimensi, siswa kelas XI SMA di Kota Banjarmasin memiliki dimensi self-efficacy yang berada pada kategori sedang. Adapun untuk siswa kelas XI SMA di Kota Palangka Raya, dimensi level dan strength berada pada kategori tinggi. Hasil ini menunjukkan bahwa tingkat keyakinan siswa kelas XI SMA di Kota Palangka Raya lebih dominan dalam menghadapi permasalahan yang sulit dan keyakinan terhadap usaha yang dilakukannya dapat memperoleh hasil yang baik. Tabel 6 menampilkan penjelasan yang lebih rinci mengenai self-efficacy siswa di Kota Banjarmasin dan Kota Palangka Raya.

Tabel 6. Self-efficacy siswa kelas XI SMA di Kota Banjarmasin dan Kota Palangka Raya

\begin{tabular}{lrlrlrl}
\hline \multirow{2}{*}{ Deskripsi } & \multicolumn{2}{c}{ Kota Banjarmasin } & \multicolumn{2}{c}{ Kota Palangka Raya } & \multicolumn{2}{c}{ Keseluruhan } \\
\cline { 2 - 6 } & \multicolumn{1}{c}{$M(S D)$} & Kategori & $M(S D)$ & Kategori & $M(S D)$ & Kategori \\
\hline Level & $39,76(7,34)$ & Sedang & $41,07(6,84)$ & Tinggi & $40,39(7,13)$ & Tinggi \\
Strength & $9,93(2,08)$ & Sedang & $10,46(2,04)$ & Tinggi & $10,18(2,08)$ & Tinggi \\
Generality & $26,72(5,64)$ & Sedang & $27,56(5,60)$ & Sedang & $27,12(5,63)$ & Sedang \\
Self-efficacy & $76,41(13,56)$ & Sedang & $79,08(13,23)$ & Sedang & $77,70(13,46)$ & Sedang \\
\hline
\end{tabular}

Dampak Perbedaan Kebijakan Zonasi terhadap Literasi Matematis dan Self-Efficacy Siswa Kelas XI SMA di Kota Banjarmasin dan Kota Palangka Raya

Analisis data dengan independent sample t-test digunakan untuk melihat dampak perbedaan kebijakan zonasi yang diterapkan di Kota Banjarmasin dan Kota Palangka Raya terhadap literasi matematis dan self-efficacy siswa kelas XISMA di kedua kota tersebut. Hasil analisis menunjukkan bahwa tidak terdapat perbedaan bermakna antara rata-rata literasi matematis siswa kelas XI SMA di Kota Banjarmasin $(M=30,65 ; S D=26,72)$ dan Kota Palangka Raya $(M=28,15 ; S D=27,22), t(665)=1,197 ; p>0,05$. Hasil ini menunjukkan bahwa perbedaan kebijakan zonasi di Kota Banjarmasin dan Kota Palangka Raya tidak berdampak pada skor literasi matematis siswa. Hasil analisis juga menunjukkan bahwa terdapat perbedaan yang bermakna antara self-efficacy siswa kelas XI SMA di Kota Banjarmasin $(M=76,41 ; S D=13,56)$ dan Kota Palangka Raya $(M=79,08 ; S D=13,23), t(665)=-2,638 ; p<0,05$. Hasil ini mengindikasikan bahwa skor rata-rata self-efficacy siswa di Kota Banjarmasin lebih rendah dari skor rata-rata self-efficacy siswa di Kota Palangka Raya.

Uji ANOVA digunakan untuk menganalisis dampak perbedaan penerapan kebijakan zonasi di Kota Banjarmasin dan Kota Palangka Raya terhadap skor rata-rata literasi matematis dan self-efficacy siswa kelas XI SMA kategori $A$, B, dan C pada masing-masing kota. Hasil uji ANOVA menunjukkan bahwa tidak terdapat perbedaan yang bermakna pada rata-rata skor literasi matematis antara sekolah kategori $A, B$, dan C di Kota Banjarmasin, $F(2,343)$ $=0,054 ; p=0,948$. Sedangkan untuk Kota Palangka Raya, terdapat perbedaan yang bermakna pada skor rata-rata literasi matematis antara sekolah kategori $\mathrm{A}, \mathrm{B}$, dan $C, F(2,318)=51,91 ; p=0,00$. Pada uji lanjut, diperoleh hasil bahwa rata-rata skor literasi matematis siswa pada sekolah kategori $C(M=5,81 ; S D=13,52)$ berbeda signifikan dengan rata-rata skor literasi matematis siswa pada sekolah kategori $A(M=38,81 ; S D=25,04), t(215)=11,04 ; p=$ 0,00 dan rata-rata skor literasi matematis siswa pada sekolah kategori $B(M=32,25 ; S D=27,94), t(185)=7,91 ; p=$ 0,00 . Adapun rata-rata skor literasi matematis sekolah kategori $\mathrm{A}(M=38,81,23 ; S D=25,04)$ dan sekolah kategori $B(M=32,25 ; S D=27,94)$ tidak terdapat perbedaan yang signifikan, $t(236)=1,88 ; p=0,062$.

Hasil uji ANOVA pada skor self-efficacy siswa di Kota Banjarmasin menunjukkan bahwa terdapat perbedaan rata-rata skor yang bermakna antara sekolah kategori $A, B, \operatorname{dan} C, F(2,343)=5,432 ; p=0,005$. Hasil uji lanjut mengindikasikan bahwa terdapat perbedaan rata-rata skor self-efficacy yang bermakna antara sekolah kategori $\mathrm{A}(M=$ $75,13 ; S D=13,69)$ dan sekolah kategori $B(M=71,26 ; S D=12,00), t=2,31 ; p=0,022$, serta dengan sekolah kategori $C(M=69,84 ; S D=12,17), t(227)=3,081 ; p=0,002$. Untuk sekolah kategori $B(M=71,26 ; S D=12,00)$ dan sekolah kategori $C(M=69,84 ; S D=12,17)$, tidak terdapat perbedaan yang signifikan pada rata-rata skor self-efficacy, $t(224)$ $=0,888, p=0,376$. Sedangkan hasil uji ANOVA pada skor self-efficacy siswa di Kota Palangka Raya menunjukkan bahwa tidak ada perbedaan rata-rata skor yang bermakna antara siswa dari sekolah kategori $A, B$, dan $C, F(2,318)$ $=1,611 ; p=0,201$. 


\section{Hubungan Literasi Matematis dan Self-efficacy Siswa Kelas XI SMA di Kota Banjarmasin dan Kota Palangka Raya}

Hubungan antara literasi matematis dan self-efficacy siswa SMA kelas XI di Kota Banjarmasin dan Kota Palangka Raya diuji menggunakan analisis korelasi Pearson. Hasil analisis menunjukkan bahwa terdapat korelasi positif yang signifikan (meskipun lemah) antara capaian literasi matematis dan self-efficacy siswa di Kota Banjarmasin dan Palangka Raya, $r=0,194 ; N=667 ; p=0,00 ; R^{2}=0,038$. Koefisien korelasi sebesar 0,194 mengindikasikan bahwa derajat hubungan antara literasi matematis dan self-efficacy siswa berada pada kategori lemah (Cohen et al., 2007). Hasil yang hampir sama juga terjadi pada data masing-masing kota. Untuk Kota Banjarmasin, terdapat korelasi positif yang signifikan (meskipun lemah) antara literasi matematis dan self-efficacy siswa, $r=0,262 ; N=346 ; p=$ 0,$000 ; R^{2}=0,069$. Sedangkan di Kota Palangka Raya, juga terdapat korelasi positif yang signifikan (meskipun lemah) antara literasi matematis dan self-efficacy siswa, $r=0,134 ; N=321 ; p=0,017 ; R^{2}=0,018$.

\section{PEMBAHASAN}

\section{Capaian Literasi Matematis Siswa SMA Kelas XI di Kota Banjarmasin dan Kota Palangka Raya}

Analisis data literasi matematis siswa di Kota Banjarmasin dan Kota Palangka Raya didominasi oleh siswa dengan capaian yang rendah. Hasil penelitian ini tidak jauh berbeda dengan hasil PISA 2018 yang menunjukkan bahwa terdapat 28\% siswa Indonesia (rata-rata OECD: 75\%) mencapai level 2 atau di atasnya dalam literasi matematis dan terdapat 1\% siswa Indonesia (rata-rata OECD: 11\%) yang mencapai level 5 atau di atasnya dalam literasi matematis (OECD, 2019a). Penelitian Hamidy dan Jailani (2019) yang mengukur literasi matematis siswa di Kalimantan Timur juga menunjukkan bahwa rata-rata kemampuan siswa berada pada level 1. Penelitian di kota-kota lain di Indonesia juga menunjukkan hasil bahwa literasi matematis siswa Indonesia masih berada pada kategori rendah (misalnya, Mahdiansyah \& Rahmawati, 2014; Rifai \& Wutsqa, 2017). Salah satu penyebab rendahnya literasi matematis siswa Indonesia adalah mereka belum terbiasa menyelesaikan soal model PISA dan hanya terbiasa menyelesaikan soal rutin (Nizar et al., 2018). Selain itu, lingkungan sosial, budaya, dan tingkat pendidikan orang tua juga mempengaruhi capaian literasi matematis siswa (Pakpahan, 2016).

Berdasarkan domain literasi matematis, terdapat perbedaan skor siswa Kota Banjarmasin dan Kota Palangka Raya pada domain konten dan konteks. Untuk domain konten, skor terendah siswa di Kota Banjarmasin adalah komponen uncertainty and data, sedangkan skor terendah siswa di Kota Palangka Raya adalah pada komponen change and relationship. Pada domain konteks, skor terendah siswa Kota Banjarmasin adalah komponen societal, sedangkan siswa Kota Palangka Raya adalah komponen scientific. Perbedaan skor pada domain proses masingmasing kota dapat terjadi karena prioritas, tugas, atau pembelajaran rutin dilakukan di kelas pada masing-masing sekolah di tiap kota juga berbeda (OECD, 2014). Rendahnya capaian literasi siswa pada domain tertentu juga dapat terjadi karena tingkat abstraksi butir soal pada konten tersebut lebih tinggi dibandingkan dengan domain lainnya (Mahdiansyah \& Rahmawati, 2014).

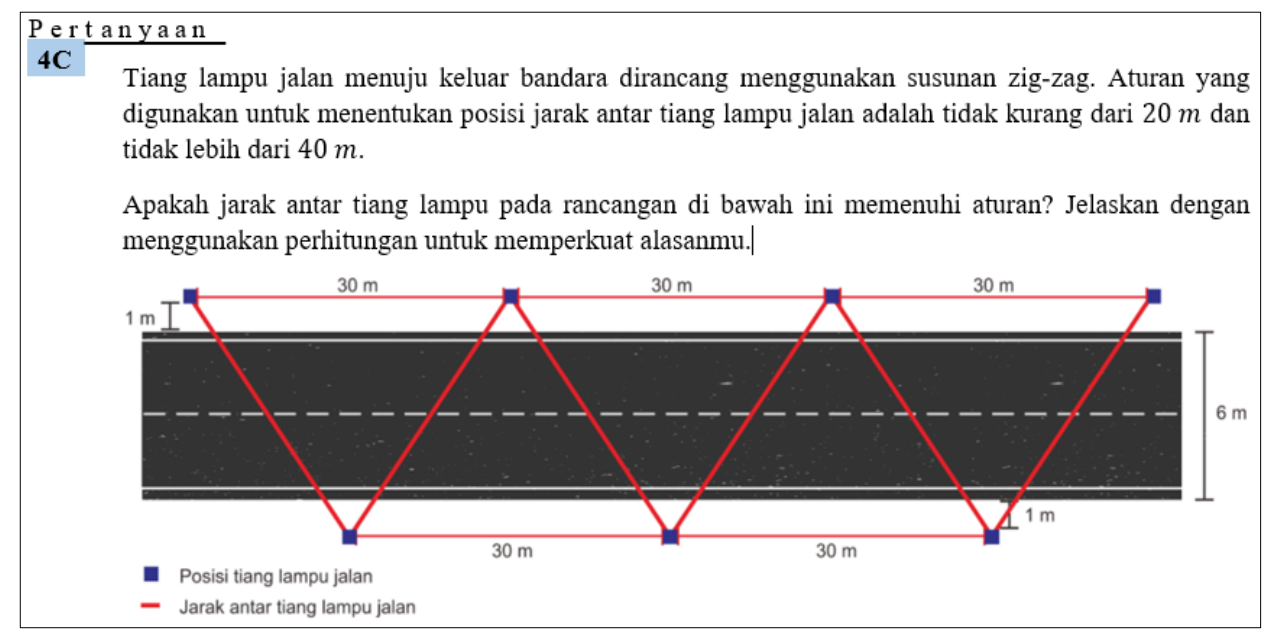

Gambar 7. Soal literasi matematis domain proses interpret 
Soal pada Gambar 7 merupakan soal dengan domain proses interpret. Soal ini merupakan bagian C soal unit 4 yang memiliki tema "Lampu Jalan". Soal ini merupakan soal dengan persentase terendah siswa, baik untuk Kota Banjarmasin maupun Kota Palangka Raya, dapat menjawab dengan benar (6,7\%). Soal dengan domain interpret menitikberatkan pada kemampuan individu untuk merefleksikan solusi atau hasil matematika, kemudian menyimpulkan dan menafsirkannya ke dalam konteks masalah kehidupan nyata. Siswa tidak cukup hanya sampai menemukan solusi, tetapi juga perlu untuk menerjemahkan atau menalar kembali solusi matematika ke konteks masalah dan menentukan apakah hasilnya sesuai atau tidak berdasarkan konteks masalah (OECD, 2019c).

Siswa harus memahami konsep geometri, khususnya teorema Pythagoras, untuk dapat menyelesaikan soal 4C. Konteks situasi yang ditampilkan terkait dengan teknologi dan ilmiah, yaitu pembangkit listrik tenaga surya, dengan demikian soal ini termasuk ke dalam domain konteks scientific. Gambar 8 (a) merupakan contoh jawaban siswa yang dikategorikan benar. Siswa mampu mengidentifikasi semua informasi dan mampu menentukan konsep dan prinsip matematika yang tepat dalam menentukan solusi. Setelah menemukan solusi, siswa juga mampu menerjemahkan kembali solusi matematika untuk memberikan kesimpulan jarak tiang lampu tidak memenuhi aturan. Selanjutnya, Gambar 8 (b) merupakan contoh jawaban siswa yang dikategorikan sebagian benar dan Gambar 8 (c) merupakan contoh jawaban siswa yang dikategorikan salah. Dalam menerjemahkan kembali solusi matematika ke konteks masalah, siswa kurang tepat dalam mengidentifikasi informasi. Siswa tidak mampu mengidentifikasi keseluruhan informasi dan tidak mampu menentukan konsep dan prinsip matematika yang tepat dalam menentukan solusi. Hasil ini menunjukkan temuan serupa bahwa siswa kesulitan dalam merepresentasikan situasi secara matematis dan mengevaluasi solusi matematika secara logis ke dalam konteks masalah dunia nyata (Edo et al., 2013).

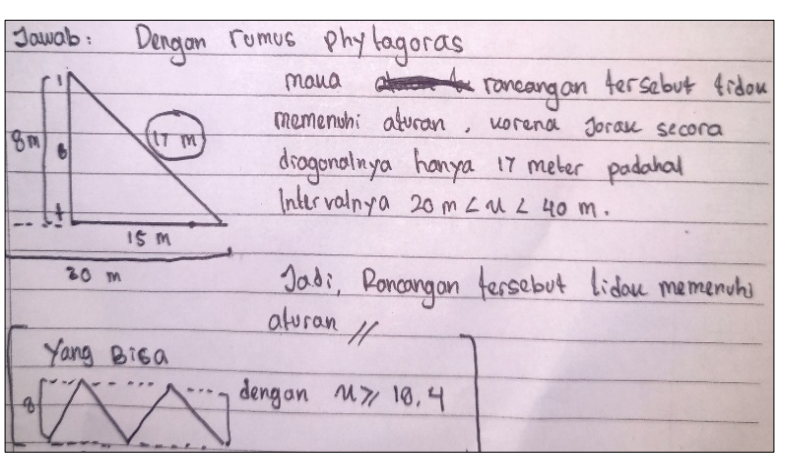

(a)

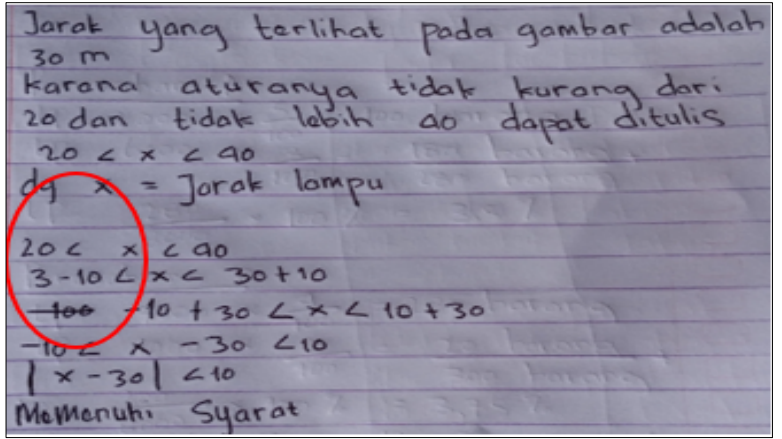

(b)

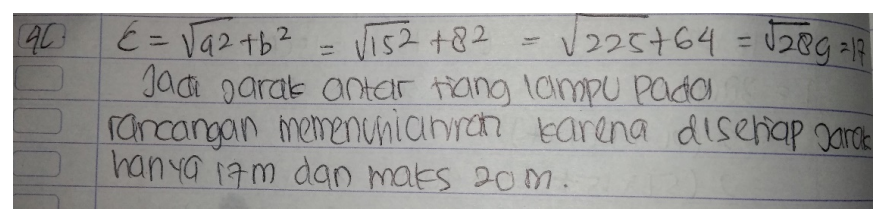

(c)

Gambar 8. Contoh jawaban beberapa siswa pada soal unit 4C: (a) jawaban siswa yang dikategorikan benar; (b) jawaban siswa yang dikategorikan sebagian benar; dan (c) jawaban siswa yang dikategorikan salah

Soal yang dibahas selanjutnya adalah soal unit 1A yang bertemakan "Kedai Teh" dengan domain proses employ (lihat Gambar 9). Semua sumber informasi yang diperlukan untuk menyelesaikan permasalahan soal termuat dalam gambar dan informasi tertulis yang ada pada soal. Dalam menyelesaikan soal ini, diperlukan koneksi antar sumber informasi (Wijaya, 2016). Berdasarkan semua informasi tersebut, siswa memerlukan keterampilan dalam mengekstrak semua informasi matematika termasuk informasi dari gambar untuk selanjutnya menggunakan konsep, fakta, prosedur, dan penalaran matematika dengan melakukan perhitungan aritmetika yang diperlukan untuk memperoleh hasil dan menemukan solusi matematika (OECD, 2019c). 


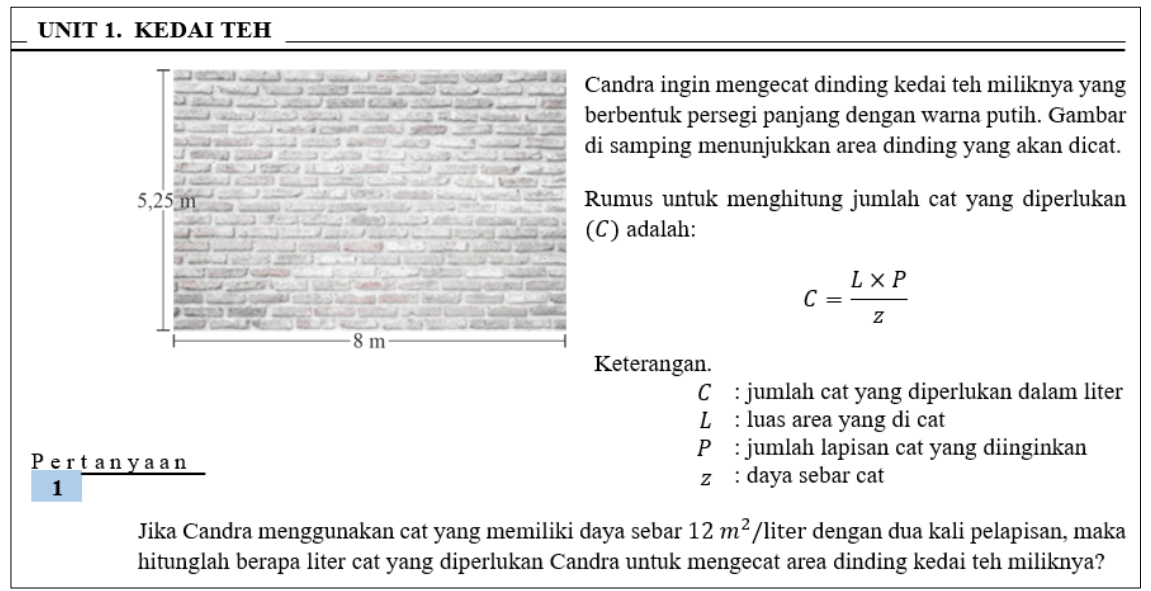

Gambar 9. Soal literasi matematis domain proses employ

Contoh jawaban siswa pada Gambar 10 (a) merupakan contoh jawaban yang dikategorikan benar. Siswa tersebut dapat mengekstrak keseluruhan informasi yang termuat pada soal, termasuk informasi gambar untuk menentukan rumus dalam memperoleh luas area yang akan dicat (L). Siswa juga mampu melakukan penghitungan aritmetika dengan tepat sehingga menghasilkan solusi permasalahan yang tepat pula. Contoh jawaban siswa pada Gambar 10 (b) dan Gambar 10 (c) secara berturut-turut merupakan contoh jawaban yang dikategorikan sebagian benar dan jawaban salah. Dalam merumuskan luas area (L) yang merupakan sebuah bangun berupa persegi panjang, siswa tidak mengalikan antara sisi satu dengan sisi lainnya melainkan menjumlahkan keduanya (dilihat berdasarkan hasil penghitungan aritmetika) sehingga menghasilkan nilai yang kurang tepat. Hal paling mendasar dalam proses employ adalah penting bagi siswa untuk mengidentifikasi semua informasi matematika yang termuat dalam permasalahan. Dalam contoh lembar jawaban tersebut, siswa mengabaikan informasi yang termuat dalam gambar pada soal. Soal unit $1 \mathrm{~A}$ merupakan soal dengan persentase siswa menjawab benar tertinggi dibandingkan soalsoal lain untuk siswa di Kota Banjarmasin dan Palangka Raya (49,5\%). Hasil PISA 2018 juga menunjukkan bahwa sebagian besar siswa Indonesia mampu menjawab pertanyaan yang melibatkan konteks yang sudah dikenal oleh siswa dan semua informasi yang diperlukan telah termuat dalam permasalahan yang diberikan (OECD, 2019d).

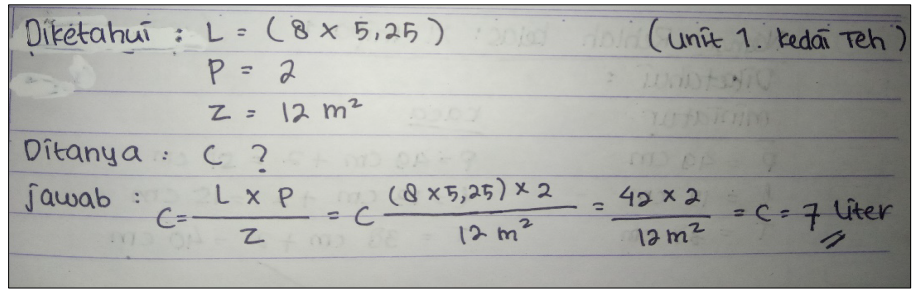

(a)

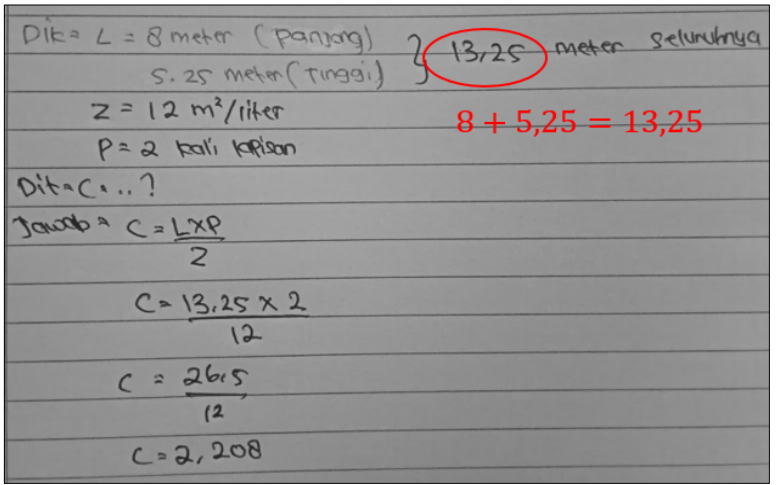

(b)

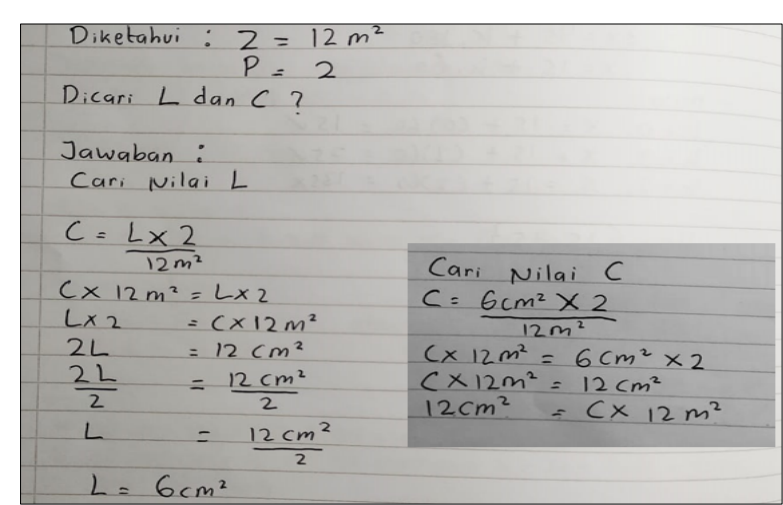

(c)

Gambar 10. Contoh jawaban beberapa siswa pada soal unit 1A: (a) jawaban siswa yang dikategorikan benar; (b) jawaban siswa yang dikategorikan sebagian benar; dan (c) jawaban siswa yang dikategorikan salah 


\section{Capaian Self-Efficacy Siswa Kelas XI SMA di Kota Banjarmasin dan Kota Palangka Raya}

Hasil analisis data menunjukkan bahwa self-efficacy siswa di Kota Banjarmasin dan Kota Palangka Raya berada pada kategori sedang. Hasil penelitian ini didukung oleh penelitian terdahulu yang memperoleh hasil bahwa ratarata self-efficacy siswa Indonesia berada pada kategori sedang (misalnya, Hadiat \& Karyati, 2019; Utami \& Wutsqa, 2017; Wasida \& Hartono, 2018). Penelitian Ahmad (2016) dan Novferma (2016) menunjukkan bahwa self-efficacy siswa di kabupaten Gowa dan kabupaten Sleman berada pada kategori tinggi. Hasil-hasil penelitian tersebut menunjukkan bahwa self-efficacy siswa Indonesia tergolong cukup baik.

Siswa dengan self-efficacy yang tinggi mampu mengatur waktu dan strategi kemandirian belajar dengan efektif, percaya diri terhadap usaha mereka sendiri, bertahan ketika dihadapkan dengan tantangan dalam belajar, memecahkan masalah konseptual, dan memiliki motivasi yang kuat (Pajares, 2002). Siswa dengan self-efficacy tinggi juga memilih dan mengidentifikasi langkah terbaik dalam menyelesaikan permasalahan (Widodo et al., 2017). Sedangkan siswa dengan self-efficacy yang rendah hampir semua dari mereka berusaha menghindari tantangan dalam matematika (Gao, 2020). Self-efficacy seseorang akan berubah seiring bertambahnya usia dan pengalaman (Huang et al., 2019; Watts et al., 2014). Meskipun perubahan tersebut terjadi, self-efficacy sebelum dan sesudah perubahan, keduanya tetap memiliki kontribusi dalam memprediksi pencapaian akademis (Phan, 2012).

Dampak Perbedaan Kebijakan Zonasi terhadap Literasi Matematis dan Self-Efficacy Siswa Kelas XI SMA di Kota Banjarmasin dan Kota Palangka Raya

Hasil uji-t menunjukkan bahwa tidak terdapat perbedaan yang bermakna antara rata-rata literasi matematis siswa di Kota Banjarmasin dan Kota Palangka Raya. Hasil ini dapat terjadi mungkin karena nilai UN (prior achievement) matematika siswa di kedua kota tersebut tidak jauh berbeda (Puspendik, 2019). Berdasarkan hasil ini, perbedaan kebijakan zonasi tidak berdampak pada perolehan literasi matematis siswa di kedua kota. Perbedaan zonasi yang diterapkan di kedua kota mengarahkan terjadinya perbedaan sebaran nilai UN sebagai prior achievement siswa pada kategori sekolah A, B, dan C. Dominasi sekolah kategori A dan B terjadi di Kota Palangka Raya, tetapi tidak demikian untuk Kota Banjarmasin. Analisis dengan uji ANOVA juga menunjukkan hasil yang sama, di mana terdapat perbedaan rata-rata literasi matematis siswa SMA di Kota Palangka Raya. Sedangkan pada Kota Banjarmasin, tidak terdapat perbedaan rata-rata skor literasi matematis. Hal ini dapat terjadi karena pada penerimaan peserta didik baru (PPDB) tahun pelajaran 2019/2020 di Kota Palangka Raya, jalur zonasi menggunakan poin jarak ditambah dengan nilai UN siswa (Dinas Pendidikan Pemerintah Provinsi Kalimantan Tengah, 2019, p. 5). Siswa dengan nilai UN tinggi dapat memilih sekolah yang diinginkan meskipun jarak tempat tinggalnya jauh dari sekolah karena unggul poin dari segi nilai UN.

Seleksi dengan mempertimbangkan nilai UN akan menyebabkan siswa dengan nilai UN tinggi berkelompok di kategori sekolah tertentu. Nilai UN sebagai prior achievement siswa dapat berpengaruh terhadap pencapaian siswa ke depannya, dalam hal ini pencapaian yang dimaksud adalah skor literasi matematis siswa itu sendiri (Hemmings et al., 2011; Manganelli et al., 2019). Hasil penelitian terhadap kemampuan literasi matematis yang dilakukan di sekolah-sekolah di beberapa kota sebelum diterapkannya kebijakan zonasi menunjukkan hasil yang serupa dengan temuan di Kota Palangka Raya yang menunjukkan bahwa skor literasi matematis lebih dominan pada sekolah dengan kategori A, kemudian diikuti sekolah kategori B, dan kategori C (misalnya, Hamidy \& Jailani, 2019; Samsuddin, 2019; Sari \& Wijaya, 2017).

Salah satu tujuan dari kebijakan sistem zonasi adalah mengurangi eksklusivitas sekolah tertentu (Kemendikbud, 2018). Tujuan tersebut terlihat pada hasil skor literasi matematis di Kota Banjarmasin untuk masing-masing kategori. Dinas pendidikan Kota Palangka Raya juga sudah tidak lagi menggunakan nilai UN sebagai salah satu pertimbangan dalam seleksi penerimaan peserta didik baru (PPDB) tahun pelajaran 2020/2021 (Gubernur Kalimantan Tengah, 2020). Berbeda dengan literasi matematis, self-efficacy siswa kelas XI SMA di Kota Banjarmasin kategori sekolah A, B, dan C menunjukkan adanya perbedaan rata-rata pada sekolah kategori A dan C. Hasil ini bisa terjadi karena siswa menganggap bahwa kesempatan untuk dapat bersekolah di sekolah yang sebelum adanya kebijakan zonasi dianggap sebagai sekolah favorit. Lingkungan sekolah dan teman sebaya yang beragam dapat membantu siswa dan meningkatkan motivasi belajar siswa menjadi lebih tinggi (Syakarofath et al., 2020). Motivasi ini memiliki kaitan dengan self-efficacy (Ajisuksmo \& Surya, 2019). 


\section{Hubungan Literasi Matematis dan Self-Efficacy Siswa Kelas XI SMA di Kota Banjarmasin dan Kota Palangka} Raya

Korelasi antara literasi matematis dan self-efficacy siswa SMA di Kota Banjarmasin dan Kota Palangka Raya memiliki korelasi yang lemah. Korelasi yang lemah memberi alasan terhadap diperolehnya self-efficacy yang baik untuk siswa kelas XI di Kota Banjarmasin dan Kota Palangka Raya, namun tidak diimbangi dengan skor literasi matematis yang baik pula. Hasil penelitian ini berlawanan dengan hasil penelitian Thien dan Darmawan (2016) dan Papanastasiou (2000) bahwa self-efficacy merupakan variabel terkuat yang paling berkorelasi dengan pencapaian matematika siswa. Namun demikian, perlu diperhatikan bahwa ada kemungkinan terdapat perbedaan persepsi bagi siswa antara permasalahan yang mereka yakin dapat diselesaikan dengan permasalahan yang diberikan. Mereka mampu dengan baik untuk menyelesaikan soal matematika rutin yang diberikan oleh guru sehari-hari, kemudian mereka menghadapi soal model PISA yang merupakan soal kompleks yang ternyata mereka kurang mampu menyelesaikannya. Perbedaan ini memberikan siswa informasi yang ambigu terkait kompetensi mereka sendiri. Sebagai konsekuensinya, self-efficacy di luar persepsi siswa mungkin tidak menghasilkan prediksi yang sama (Pietsch et al., 2003). Kemandirian dan kepercayaan diri saat berhadapan dengan matematika dalam kehidupan sehari-hari menjadi kunci sekaligus menjadi modal berharga dalam menghadapi banyaknya tumpang tindih atau perbedaan antara persiapan (contoh permasalahan dalam pembelajaran) dan permasalahan nyata (Gravemeijer et al., 2017).

\section{Implikasi}

Proses pembelajaran di kelas perlu difokuskan pada merangsang siswa untuk berpikir seperti mengintegrasikan pengetahuan untuk menjelaskan fenomena dan memecahkan masalah kompleks, bukan hanya menghafal pengetahuan (Firman, 2016). Guru sebagai tumpuan utama bagi siswa dapat menyiapkan seperangkat pembelajaran seperti RPP, LKS, dan penilaian yang berbasis literasi sehingga dapat membiasakan siswa untuk menjelaskan dan memecahkan masalah yang bersifat kompleks (Retnawati \& Wulandari, 2019).

Self-efficacy dibentuk oleh interaksi interpersonal, pengalaman sosial, dan umpan balik dari lingkungan terdekat, keluarga, teman sebaya, maupun lingkungan sekolah (Zysberg \& Schwabsky, 2020). Ini berarti, selain guru, orang tua juga berperan penting dalam pencapaian akademis anak, misal dari sikap dan keyakinan yang ditanamkan oleh orang tua pada anak-anaknya memberikan kontribusi penting terhadap tingkat pencapaian akademis mereka yang tinggi (Jerrim, 2015; Putarek \& Pavlin-Bernardic, 2020s). Sekolah dapat mengarahkan siswa untuk melihat kembali pengalaman prestasi yang baik di masa lampau, yang dapat membangun self-efficacy yang positif. Guru atau konselor sekolah dapat mendorong siswa untuk merefleksikan keberhasilan mereka di masa lalu terkait dengan keterampilan dan bakat yang dimiliki siswa untuk merencanakan keberhasilan siswa di saat ini dan di masa yang akan datang (Ajisuksmo \& Surya, 2019). Alternatif metode pembelajaran dengan memberikan permasalahan yang mempunyai beragam solusi dapat memberikan manfaat agar siswa dengan self-efficacy rendah dapat menikmati proses pembelajaran (Schukajlow et al., 2019).

Jika siswa, orang tua, guru, dan sekolah sudah berusaha dengan baik untuk melakukan tugasnya masing-masing dalam meningkatkan pendidikan, selanjutnya adalah tugas pemerintah dalam membuat kebijakan guna memfasilitasinya. Hasil penelitian yang mengukur literasi matematis siswa dapat menjadi acuan dan bahan pertimbangan dalam pembuatan kebijakan (Rautalin et al., 2019). Hal lain yang perlu diperhatikan dalam memilah ide dan pertimbangan dalam pembuatan kebijakan adalah meminimalkan adanya kesenjangan pendidikan terutama di daerah-daerah terpencil atau kawasan yang sulit terjangkau (Pratiwi, 2019). Kebijakan zonasi yang menciptakan lingkungan kelas yang beragam dapat dijadikan guru sebagai motivasi untuk meningkatkan kapasitas mereka dalam memfasilitasi dan mendukung proses pembelajaran (Syakarofath et al., 2020).

\section{SIMPULAN}

Kemampuan literasi matematis siswa kelas XI SMA di Kota Banjarmasin dan Kota Palangka Raya masih berada pada kategori rendah, sedangkan untuk self-efficacy siswa pada kedua kota tersebut berada pada kategori sedang. Tidak terdapat perbedaan yang bermakna pada rata-rata literasi matematis antara siswa di Kota Banjarmasin dan Palangka Raya. Hal tersebut menunjukkan bahwa perbedaan kebijakan zonasi pada kedua kota tidak memberikan dampak yang signifikan terhadap kemampuan literasi matematis siswa. Namun demikian, terdapat perbedaan yang bermakna pada rata-rata self-efficacy antara siswa di Kota Banjarmasin dan Palangka Raya. Hal tersebut me- 
nunjukkan bahwa perbedaan kebijakan zonasi pada kedua kota memberikan dampak yang signifikan terhadap selfefficacy siswa. Kebijakan zonasi di Kota Palangka Raya hanya menyebabkan terjadinya perbedaan rata-rata literasi matematis siswa pada sekolah kategori tinggi, sedang, dan rendah. Sedangkan kebijakan zonasi di Kota Banjarmasin hanya menyebabkan perbedaan rata-rata self-efficacy siswa pada sekolah kategori tinggi, sedang, dan rendah. Selanjutnya, penelitian ini juga mengungkapkan bahwa terdapat korelasi positif yang signifikan (meskipun lemah) antara literasi matematis dan self-efficacy siswa. Penelitian selanjutnya perlu mengkaji lebih dalam terkait kesesuaian persepsi siswa terhadap self-efficacy mereka dengan permasalahan yang dihadapi. Penelitian ini juga terbatas pada mengukur dampak zonasi terhadap literasi dan self-efficacy hanya pada sekolah negeri, sehingga perlu dilakukan penelitian lebih lanjut dengan cakupan yang lebih luas.

\section{UCAPAN TERIMA KASIH}

Terima kasih penulis sampaikan kepada Direktorat Riset dan Pengabdian Masyarakat Deputi Bidang Penguatan Riset dan Pengembangan Kementerian Riset dan Teknologi/Badan Riset dan Inovasi Nasional yang telah memberikan dana hibah penelitian Tesis Magister. Selanjutnya, terima kasih penulis ucapkan kepada LPPM Universitas Negeri Yogyakarta yang telah memfasilitasi kegiatan PPM Dana DIPA UNY tahun 2020. Terima kasih kepada dinas pendidikan Kota Banjarmasin, Bappeda Litbang Kota Palangka Raya, kepala sekolah, dan guru-guru yang telah memberikan kesempatan kepada penulis untuk melaksanakan penelitian ini.

\section{DAFTAR PUSTAKA}

Aditomo, A., \& Felicia, N. (2018). Ketimpangan mutu dan akses pendidikan di Indonesia: Potret berdasarkan survei PISA 2015. In C. C. A. Putri (Ed.), Kilas pendidikan (17th ed., pp. 1-8). Pusat Studi Pendidikan dan Kebijakan. https://doi.org/10.31227/osf.io/k76g3

Ahmad, S. R. S. (2016). Pengaruh math phobia, self-efficacy, adversity quotient dan motivasi berprestasi terhadap prestasi belajar matematika siswa SMP. Jurnal Riset Pendidikan Matematika, 3(2), 259-272. https://doi.org/10.21831/jrpm.v3i2.6138

Ajisuksmo, C. R. P., \& Surya, D. T. (2019). Efikasi diri dan strategi motivasi sebagai prediktor prestasi akademis siswa dari keluarga nelayan tradisional. Jurnal Pendidikan dan Kebudayaan, 4(1), 72-85. https://doi.org/10.24832/jpnk.v4i1.1232

Asrijanty, A. (2019). Hubungan akreditasi sekolah, hasil ujian nasional, dan indeks integritas ujian nasional. Jurnal Pendidikan dan Kebudayaan, 4(1), 1-14. https://doi.org/10.24832/jpnk.v4i1.732

Badan Standar Nasional Pendidikan. (2018). Buku saku ujian nasional 2019. Kemdikbud. https://bsnp-indonesia.org/wpcontent/uploads/2019/03/19_02_19-Buku-Saku-UN-2019-revisi-BS-20-Feb-1.pdf

Bandura, A. (Ed.). (1995). Self-efficacy in changing societies. Cambridge University Press.

Bandura, A. (1997). Self-efficacy: The exercise of control. Worth Publishers.

Carmichael, C., Callingham, R., Hay, I., \& Watson, J. (2010). Statistical literacy in the middle school: The relationship between interest, self-efficacy and prior mathematics achievement. Australian Journal of Educational \& Developmental Psychology, 10(1), 83-93. https://files.eric.ed.gov/fulltext/EJ895558.pdf

Cheema, J. R., \& Skultety, L. S. (2016). Self-efficacy and literacy: A paired difference approach to estimation of over/under-confidence in mathematics- and science-related tasks. Educational Psychology, 37(6), 652-665. https://doi.org/10.1080/01443410.2015.1127329

Cohen, L., Manion, L., \& Morrison, K. (2007). Research methods in education (6th ed.). Routledge.

Dinas Pendidikan dan Kebudayaan Pemerintah Provinsi Kalimantan Selatan. (2019). Pengumuman penerimaan peserta didik baru (PPDB) tahun pelajaran 2019/2020. https://arsip.siapppdb.com/2019/berkas/kalsel/juknis.190629073102.pdf

Dinas Pendidikan Pemerintah Provinsi Kalimantan Tengah. (2019). Pedoman pelaksanaan penerimaan peserta didik baru (PPDB) SMA, SMK, dan SLB Provinsi Kalimantan Tengah tahun pelajaran 2019/2020. https://arsip.siapppdb.com/2019/berkas/kalteng/juknis.190603131336.pdf 
Ebel, R. L., \& Frisbie, D. A. (1991). Essentials of educational measurement (5th ed.). Prentice-Hall.

Edo, S. I., Putri, R. I. I., \& Hartono, Y. (2013). Investigating secondary school students' difficulties in modeling problems PISAmodel level 5 and 6. Journal on Mathematics Education, 4(1), 41-58. https://doi.org/10.22342/jme.4.1.561.41-58

Firman, H. (2016). Diagnosing weaknesses of Indonesian students' learning. In L. M. Thien, N. A. Razak, J. P. Keeves, \& I. G. N. Darmawan (Eds.), What can PISA 2012 data tell us? (pp. 63-80). Sense Publishers. https://doi.org/10.1007/97894-6300-468-8_5

Gao, J. (2020). Sources of mathematics self-efficacy in Chinese students: A mixed-method study with Q-sorting procedure. International Journal of Science and Mathematics Education, 18(4), 713-732. https://doi.org/10.1007/s10763-019-09984-1

Gibson, J. L., Ivancevich, J. M., Donnelly, J. H., \& Konopaske, R. (2011). Organizations: Behavior, structure, processes (14th ed.). McGraw-Hill Education.

Gravemeijer, K., Stephan, M., Julie, C., Lin, F. L., \& Ohtani, M. (2017). What mathematics education may prepare students for the society of the future? International Journal of Science and Mathematics Education, 15(1), 105123. https://doi.org/10.1007/s10763-017-9814-6

Gubernur Kalimantan Tengah. (2020). Pedoman pelaksanaan penerimaan peserta didik baru (PPDB) SMA, SMK, dan SLB Provinsi Kalimantan Tengah tahun pelajaran 2020/2021. https://berkas.siapppdb.com/kalteng/juknis.200605003152.pdf

Hadiat, H. L., \& Karyati, K. (2019). Hubungan kemampuan koneksi matematika, rasa ingin tahu dan self-efficacy dengan kemampuan penalaran matematika. Jurnal Riset Pendidikan Matematika, 6(2), 200-210. https://doi.org/10.21831/jrpm.v6i2.26552

Hamidy, A., \& Jailani, J. (2019). Kemampuan proses matematis siswa Kalimantan Timur dalam menyelesaikan soal matematika model PISA. Jurnal Riset Pendidikan Matematika, 6(2), 133-149. https://doi.org/10.21831/jrpm.v6i2.26679

Hemmings, B., Grootenboer, P., \& Kay, R. (2011). Predicting mathematics achievement: The influence of prior achievement and attitudes. International Journal of Science and Mathematics Education, 9(3), 691-705. https://doi.org/10.1007/s10763-010-9224-5

Hoyles, C., Noss, R., Kent, P., \& Bakker, A. (2010). Improving mathematics at work: The need for techno-mathematical literacies (1st ed.). Routledge. https://doi.org/10.4324/9780203854655

Huang, X., Zhang, J., \& Hudson, L (2019). Impact of math self-efficacy, math anxiety, and growth mindset on math and science career interest for middle school students: The gender moderating effect. European Journal of Psychology of Education, 34(3), 621-640. https://doi.org/10.1007/s10212-018-0403-z

Jerrim, J. (2015). Why do East Asian children perform so well in PISA? An investigation of Western-born children of East Asian descent. Oxford Review of Education, 41(3), 310-333. https://doi.org/10.1080/03054985.2015.1028525

Kemendikbud. (n.d.). Direktorat jendral pendidikan anak usia dini, pendidikan dasar dan pendidikan menengah: Data pokok pendidikan. https://dapo.kemdikbud.go.id/

Kemendikbud. (2018). Sistem zonasi mempercepat pemerataan di sektor pendidikan. https://www.kemdikbud.go.id/main/blog/2018/06/kemendikbud-sistem-zonasi-mempercepatpemerataan-di-sektor-pendidikan

Kemendikbud. (2019). Peraturan Menteri Pendidikan dan Kebudayaan Republik Indonesia nomor 20 tahun 2019 tentang perubahan atas peraturan Menteri Pendidikan dan Kebudayaan Republik Indonesia nomor 51 tah un 2018 tentang penerimaan peserta didik baru pada taman kanak-kanak, sekolah dasar, sekolah menengah pertama, sekolah menengah atas, dan sekolah menengah kejuruan. https://jdih.kemdikbud.go.id/arsip/Permendikbud Nomor 20 Tahun 2019.pdf 
Krejcie, R. V, \& Morgan, D. W. (1970). Determining sample size for research activities. Educational and Psychological Measurement, 30(3), 607-610. https://doi.org/10.1177/001316447003000308

Kriegbaum, K., Jansen, M., \& Spinath, B. (2015). Motivation: A predictor of PISA's mathematical competence beyond intelligence and prior test achievement. Learning and Individual Differences, 43, 140-148. https://doi.org/10.1016/j.lindif.2015.08.026

Maass, K., Geiger, V., Ariza, M. R., \& Goos, M. (2019). The role of mathematics in interdisciplinary STEM education. ZDM - Mathematics Education, 51(6) 869-884. https://doi.org/10.1007/s11858-019-01100-5

Mahdiansyah, M., \& Rahmawati, R. (2014). Literasi matematika siswa pendidikan menengah: Analisis menggunakan desain tes internasional dengan konteks Indonesia. Jurnal Pendidikan dan Kebudayaan, 20(4), 452-469. https://doi.org/10.24832/jpnk.v20i4.158

Manganelli, S., Cavicchiolo, E., Mallia, L., Biasi, V., Lucidi, F., \& Alivernini, F. (2019). The interplay between self-determined motivation, self-regulated cognitive strategies, and prior achievement in predicting academic performance. Educational Psychology, 39(4), 470-488. https://doi.org/10.1080/01443410.2019.1572104

McCoach, D. B., Gable, R. K., \& Madura, J. P. (2013). Instrument development in the affective domain: School and corporate applications (3rd ed.). Springer. https://doi.org/10.1007/978-1-4614-7135-6

McCulloch, G. (1991). School zoning, equity and freedom: The case of New Zealand. Journal of Education Policy, 6(2), 155-168. https://doi.org/10.1080/0268093910060204

Moretti, G. A. S., \& Frandell, T. (2013). Literacy from a right to education perspective. UNESCO. https://www.rightto-education.org/sites/right-to-education.org/files/resourceattachments/UNESCO_Literacy_from_a_right_to_education_perspective_2013_En.pdf

Nizar, H., Putri, R. I. I., \& Zulkardi, Z. (2018). Developing PISA-like mathematics problem using the 2018 Asian games football and table tennis context. Journal on Mathematics Education, 9(2), 183-194. https://doi.org/10.22342/jme.9.2.5246.183-194

Novferma, N. (2016). Analisis kesulitan dan self-efficacy siswa SMP dalam pemecahan masalah matematika berbentuk soal cerita. Jurnal Riset Pendidikan Matematika, 3(1), 76-87. https://doi.org/10.21831/jrpm.v3i1.10403

OECD. (2000). Measuring student knowledge and skills: The PISA 2000 assessment of reading, mathematical and scientific literacy. OECD Publishing. https://doi.org/10.1787/9789264181564-en

OECD. (2013). PISA 2012 Assessment and analytical framework: Mathematics, reading, science, problem solving and financial literacy. OECD Publishing. https://doi.org/10.1787/9789264190511-en

OECD. (2014). PISA 2012 results: What students know and can do (volume I, revised edition, February 2014): Student performance in mathematics, reading and science. OECD Publishing. https://doi.org/10.1787/9789264208780-en

OECD. (2016a). Low-performing students: Why they fall behind and how to help them succeed. OECD Publishing. https://doi.org/10.1787/9789264250246-en

OECD. (2016b). Country note - Results from PISA 2015: Indonesia. OECD Publishing. https://www.oecd.org/pisa/PISA2015-Indonesia.pdf

OECD. (2018a). PISA 2021 mathematics framework (second draft). OECD Publishing. https://pisa2021maths.oecd.org/files/PISA 2021 Mathematics Framework Draft.pdf

OECD. (2018b). The future of education and skills: Education 2030. OECD Publishing. https://www.oecd.org/education/2030/E2030\%20Position\%20Paper\%20(05.04.2018).pdf

OECD. (2019a). Country note - Results from PISA 2018: Indonesia. OECD Publishing. http://www.oecd.org/pisa/publications/PISA2018_CN_IDN.pdf

OECD. (2019b). OECD multilingual summaries PISA 2018 results (volume I) what students know and can do: Summary in Indonesian. OECD Publishing. https://read.oecd.org/10.1787/694c168b-id?format=pdf 
OECD. (2019c). PISA 2018 assessment and analytical framework. OECD Publishing. https://doi.org/https://doi.org/10.1787/b25efab8-en

OECD. (2019d). PISA 2018 results (volume I): What students know and can do. OECD Publishing. https://doi.org/10.1787/5f07c754-en

OECD \& UNESCO Institute for Statistics. (2003). Literacy skills for the world of tomorrow: Further results from PISA 2000. OECD Publishing. https://doi.org/10.1787/9789264102873-en

Opertti, R. (2017). 15 clues to support the education 2030 agenda. In R. Opertti, G. Magni, I. Siakalli, \& H. Kang (Eds.), Current and critical issues in curriculum, learning and assessment. IBE UNESCO International Bureau of Education. https://unesdoc.unesco.org/ark:/48223/pf0000259069

Pajares, F. (2002). Gender and perceived self-efficacy in self-regulated learning. Theory into Practice, 41(2), 116-125. https://doi.org/10.1207/s15430421tip4102_8

Pajares, F. (2005). Gender differences in mathematics self-efficacy beliefs. In A. M. Gallagher \& J. C. Kaufman (Eds.), Mind the gap: Gender differences in mathematics (pp. 294-315). Cambridge University Press. https://doi.org/10.1017/CBO9780511614446.015

Pakpahan, R. (2016). Faktor-faktor yang memengaruhi capaian literasi matematika siswa Indonesia dalam PISA 2012. Jurnal Pendidikan dan Kebudayaan, 1(3), 331-348. https://doi.org/10.24832/jpnk.v1i3.496

Papanastasiou, C. (2000). Internal and external factors affecting achievement in mathematics: Some findings from TIMSS. Studies in Educational Evaluation, 26(1), 1-7. https://doi.org/10.1016/S0191-491X(00)00002-X

Phan, H. P. (2012). Informational sources, self-efficacy and achievement: A temporally displaced approach. Educational Psychology, 32(6), 699-726. https://doi.org/10.1080/01443410.2012.708320

Pietsch, J., Walker, R., \& Chapman, E. (2003). The relationship among self-concept, self-efficacy, and performance in mathematics during secondary school. Journal of Educational Psychology, 95(3), 589-603. https://doi.org/10.1037/0022-0663.95.3.589

Pratiwi, I. (2019). Efek program PISA terhadap kurikulum di Indonesia. Jurnal Pendidikan dan Kebudayaan, 4(1), 5171. https://doi.org/10.24832/jpnk.v4i1.1157

Puspendik. (2019). Laporan hasil ujian nasional: Penguasaan materi ujian nasional. Kementerian Pendidikan dan Kebudayaan. https://hasilun.puspendik.kemdikbud.go.id/

Putarek, V., \& Pavlin-Bernardic, N. (2020). The role of self-efficacy for self-regulated learning, achievement goals, and engagement in academic cheating. European Journal of Psychology of Education, 35, 647-671. https://doi.org/10.1007/s10212-019-00443-7

Rautalin, M., Alasuutari, P., \& Vento, E. (2019). Globalisation of education policies: Does PISA have an effect? Journal of Education Policy, 34(4), 500-522. https://doi.org/10.1080/02680939.2018.1462890

Retnawati, H., \& Wulandari, N. F. (2019). The development of students' mathematical literacy proficiency. Problems of Education in the 21st Century, 77(4), 502-514. https://doi.org/10.33225/pec/19.77.502

Rifai, R., \& Wutsqa, D. U. (2017). Kemampuan literasi matematika siswa SMP negeri se-Kabupaten Bantul. Jurnal Pendidikan Matematika dan Sains, 5(2), 152-162. https://doi.org/10.21831/jpms.v5i2.15747

Samsuddin, A. F. (2019). Kemampuan literasi matematika dan self-efficacy siswa SMP negeri di kota Makassar. [Master's thesis, Universitas Negeri Yogyakarta]. http://eprints.uny.ac.id/66196/

Sari, R. H. N., \& Wijaya, A. (2017). Mathematical literacy of senior high school students in Yogyakarta. Jurnal Riset Pendidikan Matematika, 4(1), 100-107. https://doi.org/10.21831/jrpm.v4i1.10649

Schleicher, A. (2007). Can competencies assessed by PISA be considered the fundamental school knowledge 15-yearolds should possess? Journal of Educational Change, 8, 349-357. https://doi.org/10.1007/s10833-007-9042-x 
Schleicher, A. (2019). PISA 2018: Insights and interpretations. OECD Publishing. https://search.oecd.org/pisa/PISA\%202018\%20Insights\%20and\%20Interpretations\%20FINAL\%2OPDF.pdf

Schukajlow, S., Achmetli, K., \& Rakoczy, K. (2019). Does constructing multiple solutions for real-world problems affect self-efficacy? Educational Studies in Mathematics, 100, 43-60. https://doi.org/10.1007/s10649-018-9847-y

Simon, R. A., Aulls, M. W., Dedic, H., Hubbard, K., \& Hall, N. C. (2015). Exploring student persistence in STEM programs: A motivational model. Canadian Journal of Education, 38(1), 1-27. https://journals.sfu.ca/cje/index.php/cjerce/article/view/1729

Stacey, K., \& Turner, R (Eds.). (2015). Assessing mathematical literacy: The PISA experience. Springer. https://doi.org/10.1007/978-3-319-10121-7

Syakarofath, N. A., Sulaiman, A., \& Irsyad, M. F. (2020). Kajian pro kontra penerapan sistem zonasi pendidikan di Indonesia. Jurnal Pendidikan dan Kebudayaan, 5(2), 115-130. https://doi.org/10.24832/jpnk.v5i2.1736

Thien, L. M., \& Darmawan, I. G. N. (2016). Factors associated with Malaysian mathematics performance in PISA 2012. In L. M. Thien, N. A. Razak, J. P. Keeves, \& I. G. N. Darmawan (Eds.), What can PISA 2012 data tell us? (pp. 81105). Senses Publishers. https://doi.org/10.1007/978-94-6300-468-8_6

Tossavainen, T., Rensaa, R. J., \& Johansson, M. (2019). Swedish first-year engineering students' views of mathematics, self-efficacy and motivation and their effect on task performance. International Journal of Mathematical Education in Science and Technology, 1-16. https://doi.org/10.1080/0020739X.2019.1656827

Tutkun, O. F., Erdogan, D. G., \& Ozturk, B. (2014). Levels of visual mathematics literacy self-efficacy perception of the secondary school students. Middle Eastern \& African Journal of Educational Research, 8, 19-27.

Utami, R. W., \& Wutsqa, D. U. (2017). Analisis kemampuan pemecahan masalah matematika dan self-efficacy siswa SMP negeri di Kabupaten Ciamis. Jurnal Riset Pendidikan Matematika, 4(2), 166-175. https://doi.org/10.21831/jrpm.v4i2.14897

Wasida, M. R., \& Hartono, H. (2018). Analisis kesulitan menyelesaikan soal model ujian nasional matematika dan selfefficacy siswa SMA. Jurnal Riset Pendidikan Matematika, 5(1), 82-95. https://doi.org/10.21831/jrpm.v5i1.10060

Watts, T. W., Duncan, G. J., Siegler, R. S., \& Davis-Kean, P. E. (2014). What's past is prologue: Relations between early mathematics knowledge and high school achievement. Educational Researcher, 43(7), 352-360. https://doi.org/10.3102/0013189X14553660

Widodo, K., Budiarto, M. T., \& Lukito, A. (2017). Profil pemecahan masalah kreatif siswa MA ditinjau dari tingkat math self-efficacy. Jurnal Riset Pendidikan dan Inovasi Pembelajaran Matematika, 1(1), 11-18 https://doi.org/10.26740/jrpipm.v1n1.p11-18

Wiedarti, P., \& Laksono, K. (Eds.). (2016). Desain induk gerakan literasi sekolah. Kementerian Pendidikan dan Kebudayaan. http://repositori.kemdikbud.go.id/39/1/Desain-Induk-Gerakan-Literasi-Sekolah.pdf

Wijaya, A. (2016). Students' information literacy: A perspective from mathematical literacy. Journal on Mathematics Education, 7(2), 73-82. https://doi.org/10.22342/jome.v7i2.3532

Wijaya, A., van den Heuvel-Panhuizen, M., Doorman, M., \& Robitzsch, A. (2014). Difficulties in solving contextbased PISA mathematics tasks: An analysis of students' errors. Mathematics Enthusiast, 11(3), 555-584. https://scholarworks.umt.edu/tme/vol11/iss3/8

Zysberg, L., \& Schwabsky, N. (2020). School climate, academic self-efficacy and student achievement. Educational Psychology, 1-16. https://doi.org/10.1080/01443410.2020.1813690 